\title{
Holy text hermeneutics
}

\author{
Pro. Dr.Ehsan Ali Abdul-Ameer Al-Haidari \\ Philosophy of Religion and Ethics \\ College of Art Baghdad University \\ E-Mail: ehsan69ali@gmail.com
}

Tel. 07728112340

\begin{abstract}
In our current research, we deal with the topic of religious hermeneutics, so the beginning will be with the search for the roots of hormonalism in Greek philosophy. Then how it was addressed in the interpretation of religious texts in Jewish thought. Then we move to the subject that was tackled in the interpretation of religious texts in the Christian thought by considering to the most prominent philosophical and theological characters that dealt with holy texts from hermeneutic angle. Also to talk about the most important approaches of interpretation that was used by philosophers and theologians in the interpretation of holy texts, the most prominent was the literal and symbolic approaches. The first approach focused on the basic grammatical rules of words, while the second one focused on the metaphorical interpretation of religious phrases. Our beginning was with the first character to deal with the Hermeneutics religion is Philo in the first century AD, and we ended with the first character mentioned the word "Hermeneutics" as a major title in one of his books and that is Dannhawero in the seventh century.
\end{abstract}

Keywords: Spatial variation, Industrial sediments, Change Detection.

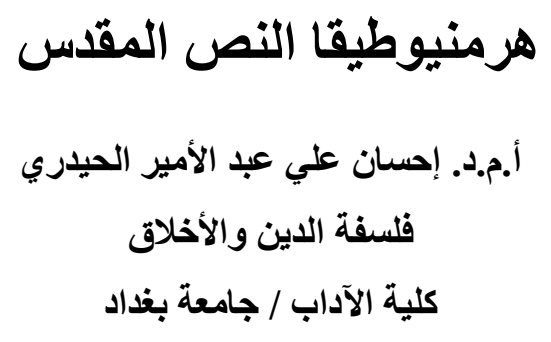

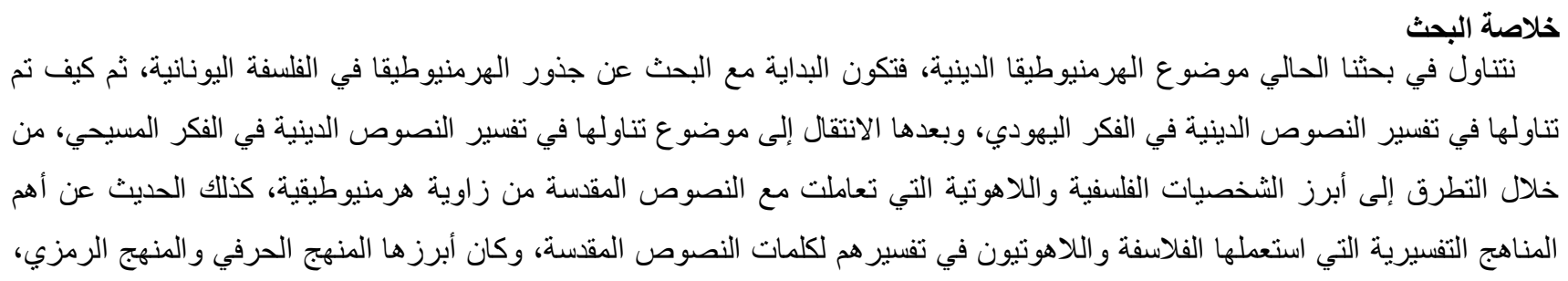




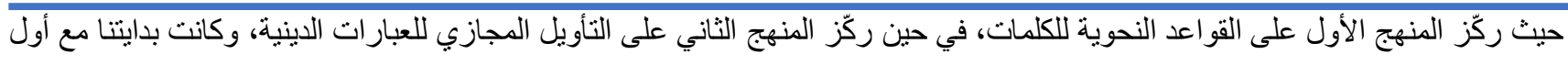

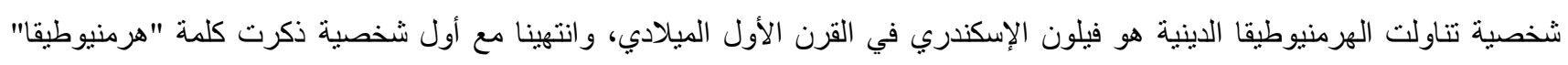

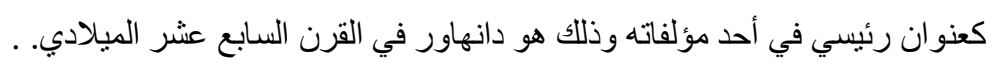
الكلمات المفتاحية: كلمات مفتاحية: الهرمنيوطيقا، النص المقدس، التأويل، التفسير، فلسفة الدين.

الذي يشهذ اتساعاً واسعاً في يومنا هذا من زاوية تعامله مع

شتى النصوص.

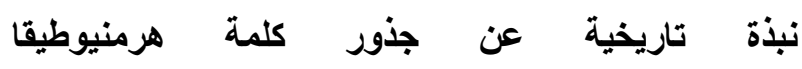

\section{:Hermeneutics}

حينما نتوجه إلى تقليب صفحات الكتب المعنية

بموضوع الهرمنيوطيقا نجد أن كلمة "هرمنيوطيقا" متجذرة من كلمة "هرمس" التي تعني المفسر أو الثنارح، وفي محاورة "أيون" من محاورات أفلاطون نجد أن أفلاطون قد تد استععل مصطلح "hermeneia" بمعنى تفسير كلمات الآلهة، وكانت نظرته إلى الشعراء بوصفهم مفسري كلام

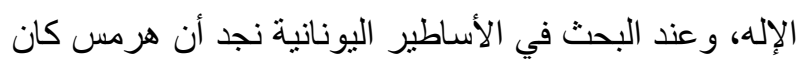

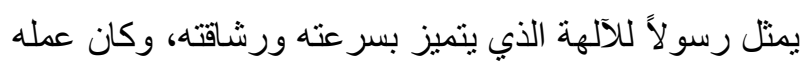
يتمثل في نقل رسائل آلهة الأولمب إلى الجنس البشري، ويتميز بقدرته على تجسير الفجوة بين العالم الإلهي والعالم

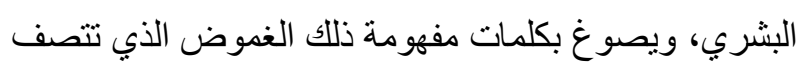
به عبار ات الآلهة ليوصلها بشكل مفهوم إلى العالم البشري؛

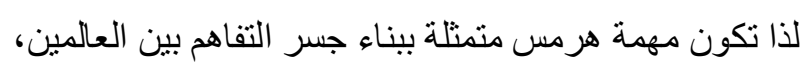
وجعل ما يبدو لا عقلي شيئاً ذي معنى ومفهوماً للأن لئن

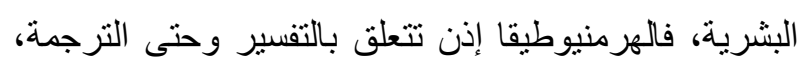

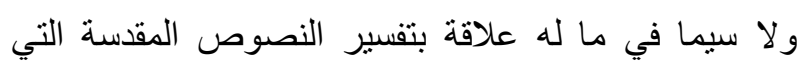

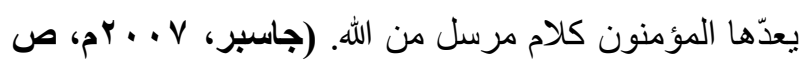

(rY Y T)

كذلك نجد في عملية تقليينا لصفحات تلك الكتب محاولات عديدة للكُتّاب العرب تتمثل في إيجاد مصطلح يقابل مصطلح

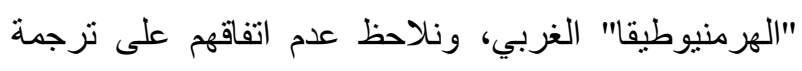
موحدة، فنجد منهم على سبيل المثال من يصطلح عليه "علم

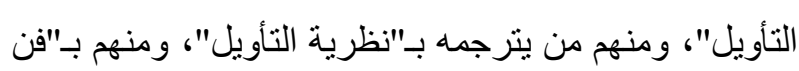

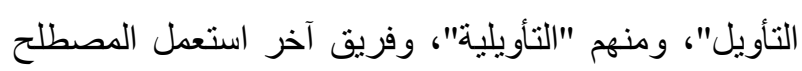
نفسه من دون إيجاد مفردة عربية تقابله، وبالمقابل نجد فريقاً
من يجوب عو الم فلسفة الدين سيتوقف لا محالة أمام

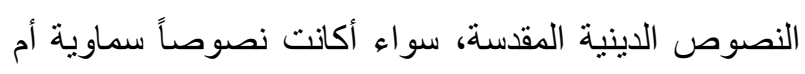

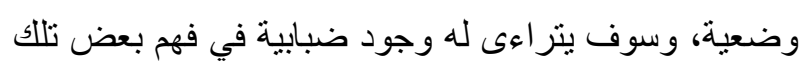

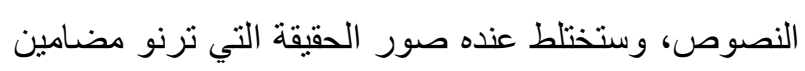
تللك النصوص في إيصال القارئ إليها، وسبلاحظ وجود تناقضات بين نص وآخر في أي كتاب مقد، وسيجد أساطير

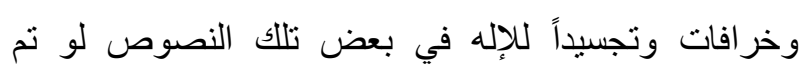

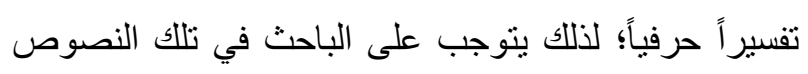
أن يلبس نظارة التفحص و التمعن؛ ليدرك مغزى النص الخفي الذي قد لا يُرى بالعين المجردة، وعندها سيدخل إلى حلبة

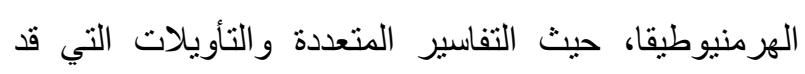
تأخذنا إلى مجاهل لم تخطر على بالنا؛ لنكتشف من خلالها كنوزاً مخفية. وفي هذا البحث المحدد بصفحات معدودة بحسب مقتضيات البحث الأكاديمي، حاولت الاخول في عمث البناء الهرمنيوطيقي؛ للتعرف على أسسه التي تم بناؤه عليها، وعثرت على أول أساس تم استعمال الهرمنيوطيقا فيه، ألا وهو الأساس الديني، إذ نم تشييد البناء الهرمنيوطيقي بشكل واضح في بداية الأمر على قاعدة النصوص الدينية، وتحديداً مع النصوص المقدسة لدى اليهود، ثم تلاها بعد ذللك مع النصوص المقدة المسيحية، وبعدها تطور الحال ليمند البناء الهرمنيوطيقي على قواعد النصوص الأدبية و القانونية و الفلسفية وغير ها، وسوف أقف في مسار بحثي الحالي عند ذلك التمدد والتوسع في البناء الهرمنيوطيقي، آملاً أن تكون

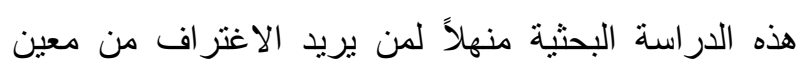
الهرمنيوطيقا، سواء في المجال الديني أو الفلسفي أو بقية

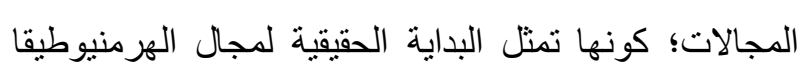


إن عملية التأويل في الاستعمال اليوناني يمكن أن تثير إلى الى

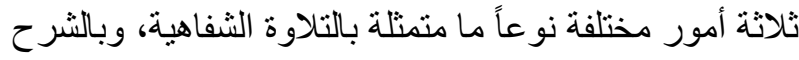

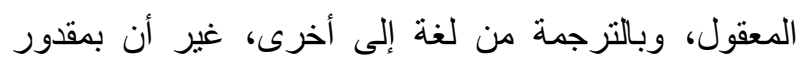

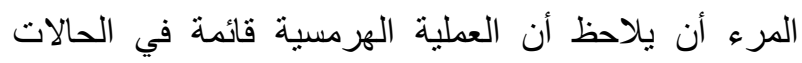

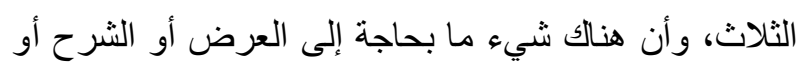

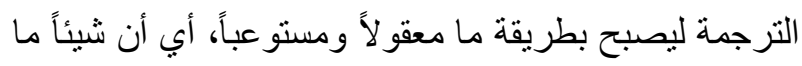

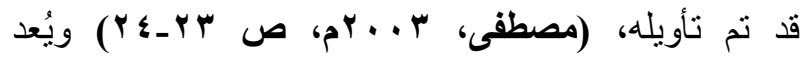
أرسطو أول من استعمل مصطلح "الهرمنيوطيقا" من خلال جعله عنواناً لأحد أبحاثه حول منطق القضايا في كتابه "الأرغانون"، ذلك أن علم الدلالة عند اليونان لا يغفل بأن قول شيءٍ ما عن شيءٍ آخر معناه قول شيء آخر ، أي تأويله.

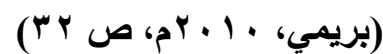

\section{لغة النص الديني وعملية التأويل في الفكر اليهودي:}

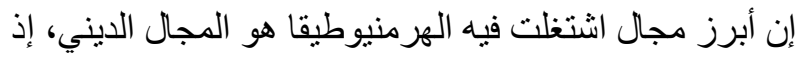
نجد أن رجال الدين قد عمدوا إلى تأويل الكتاب المقدس ليوصلوه إلى عامة الناس بسيطاً وواضحاً، ومن ثم فقد لعبو الى لهابل دور الوسيط (هرمس) الذي كان ينقل كلام الآلهة ويؤوله بطريقة تكون مفهومة للبشر، وفي هذه الحالة نجد أن رجال الدين عملوا على تنصيب أنفسهم أوصياء على الناس و التحكم في شؤون حياتهم الدينية والدنيوية، وتتميز الهرمنيوطيقا عن التفسير الاعتيادي للنصوص بكونها تمنل منهج هذا التفسير فضلاً عن أحكامه و أصوله، فلو افترضنا أن التفسير كان وقفاً على التعليق الفعلي أو الثرح، فإن الهرمنيوطيقا تمثل قواعد

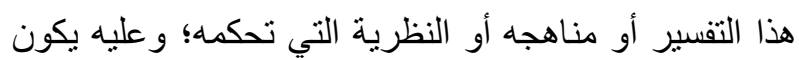
التفسير جزءاً أو آلية من آليات الهرمنيوطيقا، والهرمنيوطيقا في علم اللاهوت تعارف عليها بأنها فن تأويل الكتابات المقدة تأويلاً صحيحاً، بحيث يحاول المؤول أو المفسر الديني أن يستشعر روحانية الكتاب المقدس ويوصلها إلى لئ الآخرين مع جملة القواعد والمعايير التي يتضدنها الكتاب.

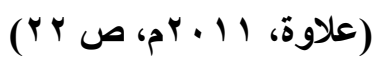

وقد عرف العهد القديم هرمنيوطيقا من هذا النوع، ولا سيما مع الديانة اليهودية، إذ قام رجال الدين اليهودي بترنيب

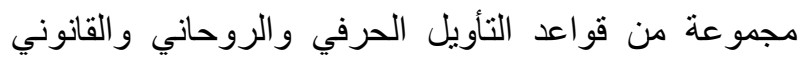
لتفسير النص التوراتي؛ ما تسبب في التفريق بين المعنى الحرفي و المعنى الرمزي (المجازي) لكلمات النص المقد،
آخر عمد إلى نرجمة المصطلح بـ"علم التفسير"، ومنهم ترجمه بـ"نظرية التفسير"، ومنهم بـ"التفسيرية"؛ وذللك ناتج عن كون الترجمة المأخوذة من الثقافة الفرنسية تثير إلى لى بـ التأويل، في حين أن الترجمة المأخوذة من الثقافة الإنكليزية تثير إلى معنى التفسير، وتعرف الهرمنيوطيقا في المعاجم الغربية على أنها عملية تأويل النصوص، وتهتم بتأويل النصوص الدينية المقدة بنحو خاص، ورلا سيما الرمزية

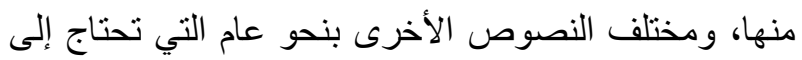

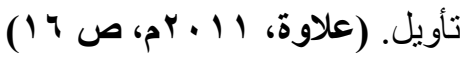
إن البحث عن جذور كلمة "هرمنيوطيقا" يدلنا على كونها مشتقة من الفعل اليوناني "hermeneuein" الذي يعني لهني "يُفسر أو يؤول"، والاسم "hermeneia" الذي يعني "تفسير أو تأويل"، وتتضمن الأشكال المختلفة لهذه الكلمة عملية إفهام شيء أو ظرف يلفه الغموض، كذلك نجد أن اليونانيين قد نسبوا عملية اكتشاف الخط واللغة إلى هرمس، وهذان الأمران يمثلان أداتين من أدوات نقل المعاني للآخرين، وقد كانت عملية إفهام الآخرين تمثل مهمة هرمس الأساسية،

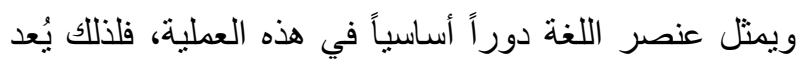
هرمس جسراً لتفسير الرسائل المرسلة من الآلهة وشرحها من خلال تحوير مضمونها وماهيتها التي تكون أعلى من من من التهني مستوى الفهم البشري من أجل إيصالها إلى البشر بشكل واضح ومفهوم، وقد عدّ بعض الباحثنين البناء الثناثي لعملية التفسير شاهد صدق على هذا الاشتقاق وعلى العلاقة بين كلمة

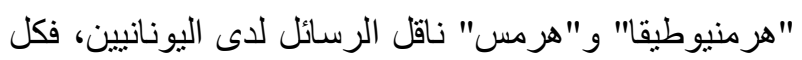

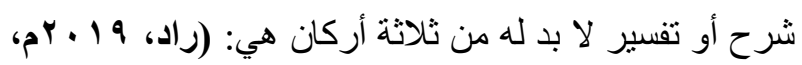

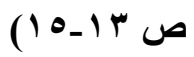

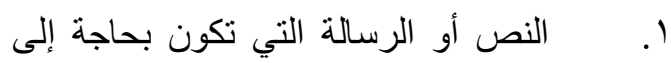
التفسير و الفهم. r. المفسر الذي يعد واسطة عملية الفهر و المتمثل بشخصية هرمس.

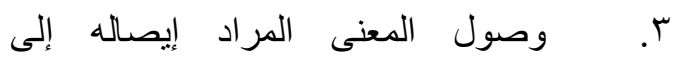
المخاطبين. و هذه البنية العامة تشتمل على أهم الموضوعات في الهرمنيوطيقا من قبيل ماهيّة النص، والمر اد من فهم النص، و آلية تأثير القبليات في فهم النص. 


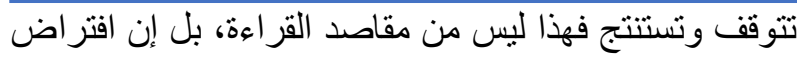
هذا الادعاء يتضمن سوء فهم ويكون كل من يفترض هذا

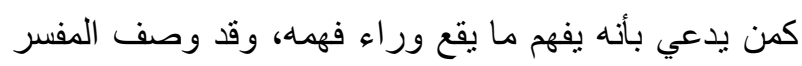

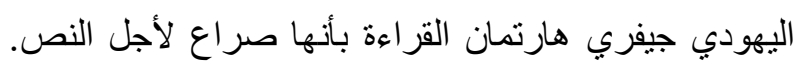

$$
\text { ( })
$$

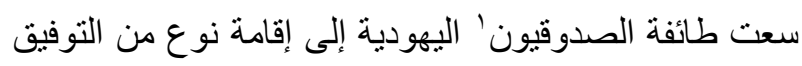
بين أصول الكتاب المقدس والفكر اليوناني، وذلك بالاعتماد

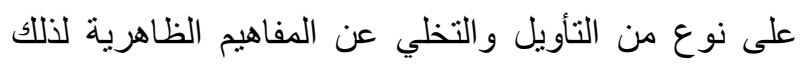
الكتاب، لكنهم لم ينجحوا في الكثير من الموارد، وقد أدى بهم ذلك إلى إنكار الكثير من المعتقدات الأساسية كالقيامة والملائكة و المكاثفات الجديدة، وفي المقابل نجد أن طائفة

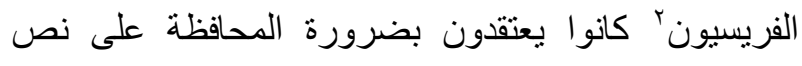
التوراة وشريعة موسى دون أي تأويل، غير أن التفاعل الثقافي لليهود مع الثعوب الأخرى أدى إلى نوع من المنهج

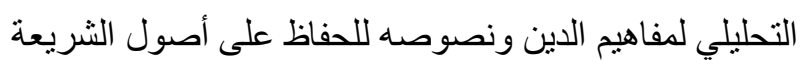
بحسب مقتضيات الزمان، وكان حاصل هذه الجهود أن ظهرت لاى اليهود مجموعة من النصوص التفسيرية

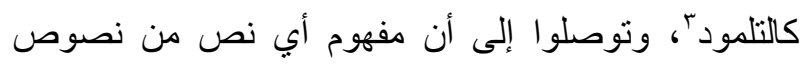
الكتاب المقد لا يمكن أن يحد في حدود معناه الظاهري و اللغوي، بل كلما تم بذل المزيد من الجهود في فهمه وتحليله عُثر على المزيد من كنوز التعاليم الدينية والأخلاقية، ويُعد بلئ

' الصدوقيون: إحدى فرق الديانة اليهودية، اعترفوا بقدسية الأسفار الخمسة من العهد القديم التي تتسب إلى موسى عليه السلام دون غيرها، كذللك أنكروا مسألة وجود حياة بعد الموت، ورفضوا الاعتر اف بوجود مخلوقات روحية منل الملائكة والشياطين، وكان جُل اهتمامهم منصباً على رونى بالمنطق. ץ الفريسيون: إحدى فرق الديانة اليهودية، كان مذهبهم متشدداً في الحفاظ على شريعة ا موسى عليه السلام و السنن الثفهية

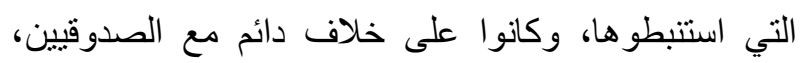
وكان أغلب علماء الكتاب المقدس ينتمون إليهح.

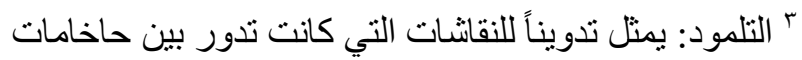
اليهود بثأن الثريعة اليهودية والمسائل الأخلاقية و الاجتماعية، كذلك يمثل مصدر اً أساسياً للتشريعات القانونية.

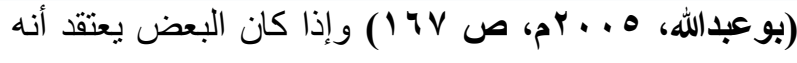
بإمكانه الوصول إلى المعنى الحرفي لكلمات النص المقدس

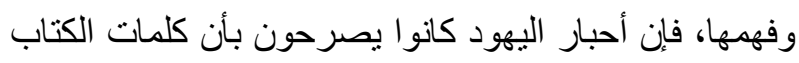

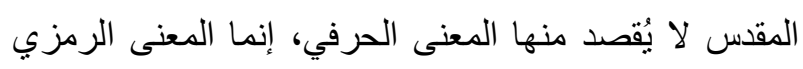

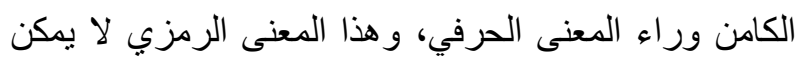

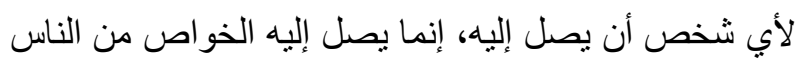
من قبيل الكهنة ورجال الدين وعلماء اللاهوت، و الهرمنيوطيقا تكون معنية بعملية فلك الرموز التي تمضي من ون ونئ المعنى الظاهري إلى المعنى الكامن، فالمعنى الرمزي وكيفية

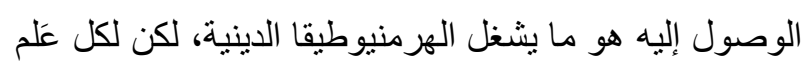
من أعلامها نظرة خاصة وهرمنيوطيقا مميزة. (علاوة، 1) إن أحبار اليهود القدامى كان لهم قر اءة للنص وفهم يختلفان عن القراءة والفهم اللذان ندرسهما، وإذا كان أساس التقليد اليوناني فلسفياً فإن التقليد العبري ليس كذلك، فاليهود لم لم يسعوا كثيراً وراء المعنى في الكلمات، بل رأوا في الكلمات

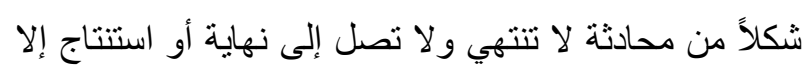

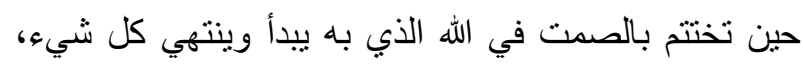

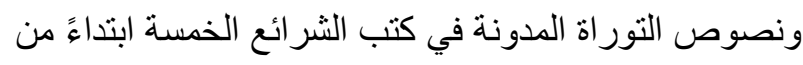
سفر التكوين إلى سفر التثنية ليست بنظر أحبار اليهود محدثة،

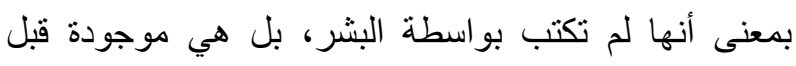

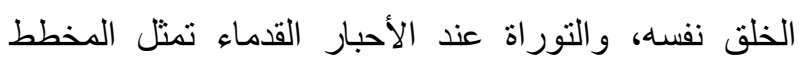

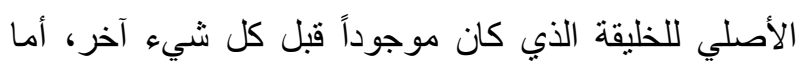

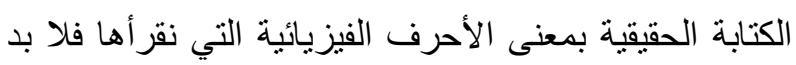
أن ننظر إليها كثوب للنصوص المقدسة المدرجة في التوراة و الموجودة منذ القدم، حيث يحمل الثكل والهيئة والعلامات في الصفحة معنى وتميزاً عميقين؛ لذلك فإن قراءة التوراة وتفسيرها ليسا مجرد محاولة لفهم معنى النص الذي هو

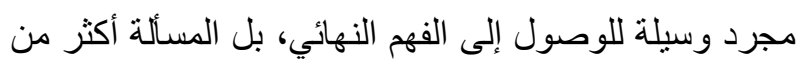
كساء للأصل اللامادي الذي هو التوراة الإلهي اللامحدود

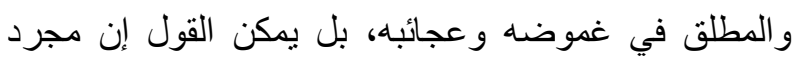

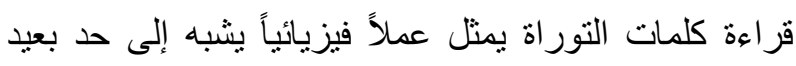
ملامسة طرف الثوب الإلهي؛ لذا فإن عملية التفسير للنص

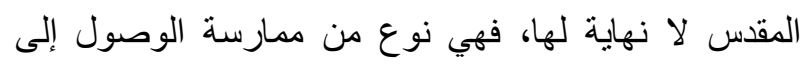

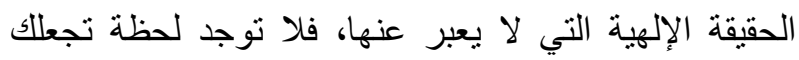


روحياً على الأقل بهذه اللفظة وأنها كانت تعني لهم الحهر الحرص الثديد على التمسك بالأمور الدينية وما يؤدي بهم في النهاية

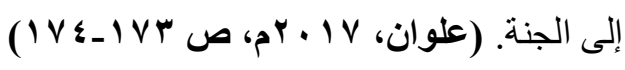
ولزيادة الإيضاح الذي ذكرناه في أعلاه ندرج في أدناه بعض ألفان التفصيل عن تلك المناهج الأربعة و على النحو الآتي: (قنديل،

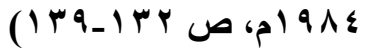
ا . البشاط: هذا المنهج يعني التفسير البسيط

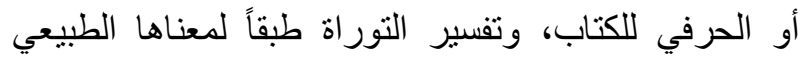
المنطقي وليس طبقاً لمعناها الوعظي، وهذا المنهج في التفسير يُعد المنهج الثائع من بين هذه المناهج، و عليه قامت معظم التفاسير منذ العصر الوسيط، فهو يهدف إلى شرح الغامض في النص أو التوسع في معناه في شكل هو أقرب إلى إلى النص، ولعل السبب في شيوع هذا المنهج وتفضيل معظم المفسرين إلى أن يسلكوا هذا الطريق هو السهولة والبساطة في الثرح و التوضيح، وعدم لجوء المفسر إلى إجهاد نفسه

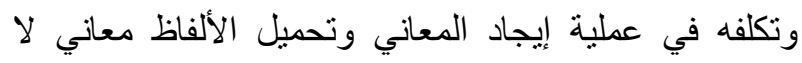
تحتملها، والابتعاد عن الإسهاب الممل المعتمد على سرد القصص والفلكلور الشعبي عند تفسير النص، وعلى الرغم من البساطة الواضحة في هذا المنهج إلا أنه يحتاج من المفسر إلى يقظة دينية وذهنية ليتمكن من التفرقة بين المعاني الحرفية للألفاظ وبين ما يدل عليه ظاهر ها في النص و إلا أوقع نفسه في المحظور كما في تفسير فقرات التشبيه و التجسيم مثناً، إذ لا يجب أن تفسر بمعناها الحرفي الظاهر، بل يفترض أن يصرف المعنى عن ظاهره مع تفسير ها مجازياً، ومن هنا لها لهان يقال إنه قد يتسبب التفسير الحرفي في أخطاء جسيمة فيما

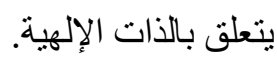
ץ. الرمز: وهذا المنهج يعني التفسيري

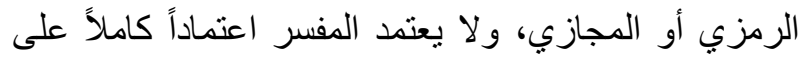
المعاني الحرفية للألفاظ، بل يحتاج إلى عو امل خارجية عن لون النص نفسه، وتظهر هنا قدرة المفسر على كشف المعاني

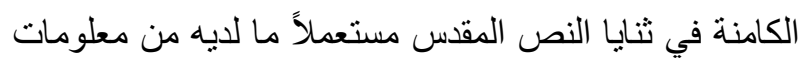
خارجية وثقافة دينية واسعة وخيال إلى غير ذلك من الوسائل التي تعينه على استخر اج المعاني المجازية في النص، وبناءً على ذلك يمكن الوقوف على الفارق بين المنهج الطبيعي و المنهج المجازي في التفسير في أن الأول يعتمد بالدرجة لين
هيلل؛ من المفسرين اليهود الذين يعتقدون أن الحياة المتغيرة للإنسان تستدعي جواز الرواية الثفوية للتوراة بغية تطبيقها

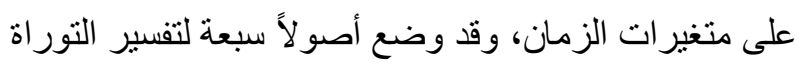
و التي تُعد أولى مر احل المشناه، ثم تطورت هذه الأصول إلى أن أصبحت اثثين وثلاثين أصلاً، وتتمحور هذه الأصول حول الإجابة عن السؤال الآتي: كيف يمكن أن نطبق مفهوماً لا صلة له بنص الكتاب المقس على نص هذا الكتاب من خلال

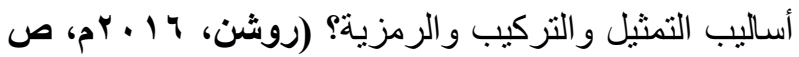

$\left(\odot \Lambda_{-} \otimes V\right.$

وفي العصر الوسيط نجد أن أحبار اليهود بدأوا بزيادة الاهتمام بنصوص التوراة ومحاولة الوقوف على ما تحتويه تللك النصوص من أحكام وشرائع وغير ذللك من الأمور التي لتي تنظم حياة الفرد و المجتمع اليهودي، فلجأو ا إلى تطوير أسلوب يتألف من أربعة مناهج لتفسير التوراة، وكل منهج منها يعطي دلالة معينة وفهماً خاصاً لمعاني ألفاظ النص ومضدونه وما قد يستفاد منه، وإن كانت هذه المناهج الأربعة يجمعها هدف واحد، هو نوضيح النص وتسهيل فهم الجماهير له كل بحسب مستو اه الفكري و الثقافي و الروحي، وقد أطلق اليهود على هذه المناهج اسم "الفردوس" التي تعني الجنة، و هذه اللفظة تمثل أوائل كلمات أربع كلها موجودة في النص العبري وهي: "بشاط" الذي يمثل المعنى الحرفي، و"رمز" الذي يمثل المعنى المجازي، و "دراش" الذي يمثل المعنى الوعظي و الأخلافي، و "سود" الذي يمثل المعنى الصوفي، فطبيعة الكتاب تكثف عن نفسها في طرق متعددة موحية بأبعاد مختلفة لسامعيه، ولعل أقرب المعاني المستفادة من الفردوس

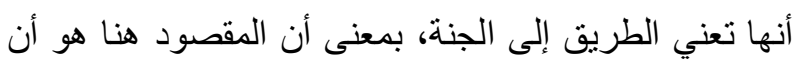

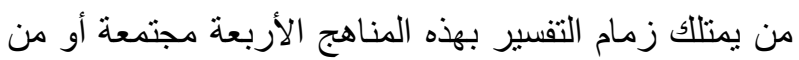
يتمكن من أن يفسر التوراة بهذه الطرق الأربعة فهو بلا شك قد بلغ درجة من العلم والثقافة والروحية والدينية تجعل بهل

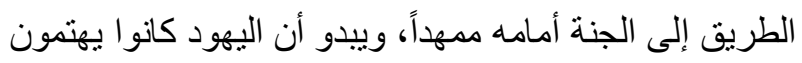

؛ هيلل: (· الق.م - · (م)، زعيم ديني يهودي، كان حكيماً وباحثاً مرتبطاً بتطوير المشناه و التلمود. • المشناه: أول ما تم تأليفه في التور اة الثفهية، ويشتمل على الثر ائع و الثروحات المتعلقة بأسفار أسفار العهد القديم. 


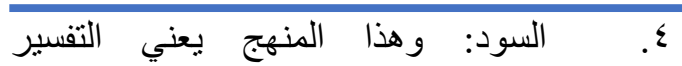

الصوفي، وتستعمل هذه اللفظة في مصطلح التفسير الديني اليهودي لكي تؤدي المعنى الباطني الخفي لألفاظ النص أو المعنى الروحاني الصوفي لها، فالنص قد يحتوي الكثير من التعاليم والأوامر و المواعظ تظهر باستمرار للمفسر فيكثف عنها، إلا أن المفسر الصوفي ينظر إلى النص المقدس وألفاظه نظرة تختلف عن غيره، فهو ينظر إليه بقلبه نظرة خلود وتنزيه، وقد يرى فيه ما ير اه مفسر البشاط والمجاز أو الدر اش، إلا أنها يزيد عليهم روحانية صوفية زائدة تجعله يرى فيه ما لا يراه غيره، ويقوم التفسير الصوفي أساساً على النظرة الدقيقة لكلمات النص عن طريق استعمال الرياضة الذهنية مع حروف الألفاظ، فهو إما أن يحسب هذه الحروف بقيمتها العددية، وإما بتغيير وتبديل الحروف و عدّها أحياناً اختصار اً لكلمات لم يشأ الله أن يكثف عنها لحكمة يعلمها، وقد ظل هذا المنهج يسير جنباً إلى جنب مع المناهج التفسيرية الأخرى ولو بدرجة أقل انتشاراً منهم، وأحياناً نجد بعض المفسرين الذين ينتهجون البشاط أو الدراش يشيرون إليه في تفاسير هم وقد يستعملونه أحياناً، و عندما انتشر مذهب القبالة؟ الصوفي في العصور الوسطى توسع هؤلاء في التفسير الصوفي مستعملين طريقة حساب الجُمّل في الحروف، وكان الهدف الذي يسعى إليه المفسر الصوفي هو أن يجعل للنص معنى أزلياً، وأن ييرهن على أن كل قراءة جديدة فيه وكل كثف جديد إنما هو وحي جديد للنص وإثبات عودة أزلية وديمومة المعاني إلى الله وحده. يعود ظهور الهرمينوطيقا الدينية إلى فيلون الإسكندري"، ويُعد المفكر المؤسس للمنهج الرمزي أي التأويل المجازي

` القبالة: مدرسة فلسفية يقوم منهجها على تفسير العلاقة بين الله السرمدي و العالم الفاني، ويعتقد متبعو هذه المدرسة أن التوجيهات و الشعائر الموجودة في القبالة تسهم في مساعدة الشخص على تطوير فهمه ليعيّ بواطن الدين. `فيلون الإسكندري: (·r ق م - • Vم)، فيلسوف ولاهوتي، يُعد أحد المصادر المهمة في التفسير اللاهوتي للايانتين اليهودية والمسيحية في القرون الأولى من المسيحية حيث كان له إنتاجاً غزيراً قارب لV مؤلف. لف.
الأولى على كلمات النص وتراكيبه وارتباط السياق العام لمعنى الفقرات، أي أن هنالك علاقة ثنائية مستمرة بين النص وبين المفسر طالما كانت العملية التفسيرية قائمة، في حين أن المفسر المجازي لا يرتبط بحرفية النص ويكون هناك فاصل بين كلمات النص و المفسر.

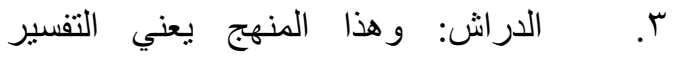
الوعظي، ويستعمل في مجال الفكر الديني اليهودي بصفة عامة، ويقوم بشرح النصوص والكتب الدينية بعيداً عن معناها الحرفي البسيط، ويعدد إلى توضيح فقرات العهد القديم لا طبقاً لمعناها البسيط، و إنما عن طريق التوسع والإضـافة والجدل، وللمفسر في هذه الحالة حرية التلاعب بألفاظ النص وإحداث تغييرات فيه وضرب الأمثلة المناسبة والقصص الوعظية التي تعينه في التأثثر على السامع أو القارئ، وأن مفسر الدراش يكاد يقترب من مفسر المجاز في أن كلاً منهما لا يرتبط ارتباطاً وثنقاً بكلمات النص ومعناها الحرفي البسيط، ويعتمد مفسر الدراش على معلومات خارجة عن النص من تجاربه ومعايشته وثقافته وخياله، و إن كان خياله يكاد أن يكون محدوداً، و على الرغم من أن البشاط كان بُعد المنهج السائد لدى اليهود إلا أن الدراش كان ينافسه هذه السيادة، بل كان أكثر منه شهرة في مر احل منفاوتة، إذ كان شائعاً بين المفسرين في المدارس الدينية المختلفة، وقد ساعد على شيوع هذا المنهج بين اليهود ما كان بسود الحياة الدينية من أمور لم يكن لها مصدر في الثريعة المكتوبة، فإن عدداً من الطقوس الدينية ذات صفة أقل قدسية وأقل جبرية قد نشأت في مرحلة ما وبعدها فرضتها الشريعة الشفوية ولم يكن لهذه الطقوس أساس في الشريعة المكتوبة، وذلك على الرغم من أن هذه الطقوس الدينية قد أخذت طابعاً اتفق عليه بين طو ائف اليهود نتيجة لهذه الممارسة الطويلة لها أو عن طريق فرض السلطات الدينية، ومع هذا فقد فطن رؤساء المدارس الدينية إلى ما قد ينتج عن التوسع في اتباع هذا المنهج والإفر اط فيه من خطورة، وحتى يضعوا ضو ابط معقولة له قرروا عدم قبول أي تقسير لا يتفق مع المعنى البسيط للنص، ولعل ذللك ما دفع بعض مفسري العصر الوسيط إلى أن يمزجوا منهجي البشاط والدر اش ويستعملونها جنباً إلى جنب في تفاسير هم. 


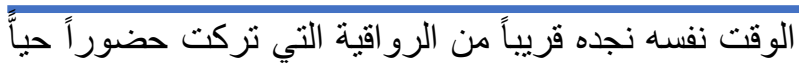
وفاعلاً في منهجه الرمزي الذي تميز به من خلال تأويل

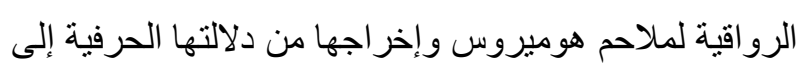

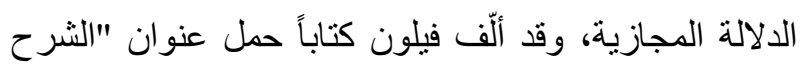
المجازي للشرائع المقدسة" الذي حرص فيه على تأويل نصوص التوراة، ولا سيما سفر التكوين تأويلاً نظرياً مشبعاً بالفلسفة اليونانية، فكان يدعم تفسيراته بمختارات من هذه الفلسفة، و لا سيما أفلاطون، لكنه كان يقف في نتأويله للإلهيات عند حدود الثريعة، بمعنى أنه يقف عند حدود حاكمية

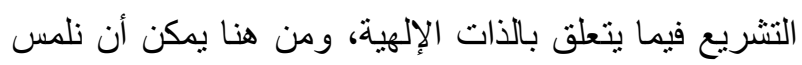

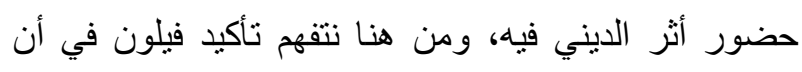
النص التور اتي يمثل مجمو عة من الرموز التي ينبخي تأويلها حتى تبعث فيها الروح، بمعنى جعلها مقتربة من فضاء المنلقي للتور اة الذي يعيش في محيط ثقافي مختلف عمّا كانت التوراة في وطنها وجمهور ها، حيث كانت وليدة بيئة فقيرة ثقافياً، ولكن فيلون - في زمانه ـ يعيش في بيئة أكثر تطور اً

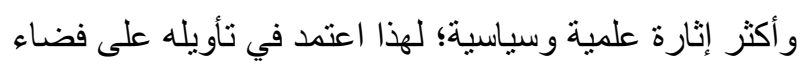

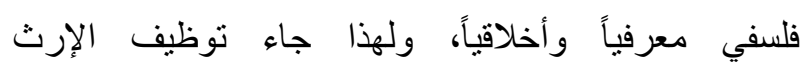
الأفلاطوني لدى الأفلاطونية المحدثة التي اعتمدت على فلسفة أفلاطون المعدلة انطلاقاً من تللك المؤثرات وتلك التحديات، إذ الذ التهي عمد فيلون إلى شرح رموز التوراة، فكان إذا قرأ نصاً مثل (الكاهن الأعظم يخلع رداءه قبل أن يدخل قدس الأقداس)،

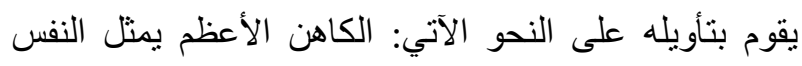
الإنسانية، وإن عملية خلع الرداء بمنزلة التخلص من سيطرة الاتئه

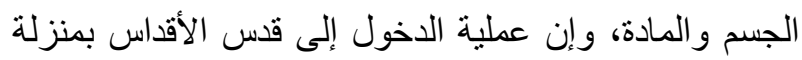

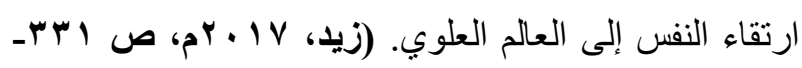

(rrr

نلاحظ مما سبق أن فيلون قد قرأ النص المقدس بعيون و أفهام اليونان، فقرر بأنه يجب في أكثر الأحيان وضع لدان

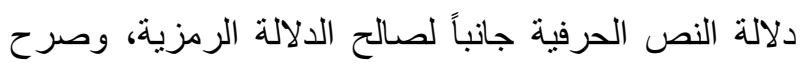
بأن النص لا يشتمل على معنى واحد بل عدة معان، وقد كان

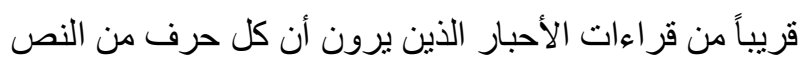
الإلهي المقدس له تميز خاص مليء بالمعاني العميقة، وقد أدى به تفكيره الانتقائي هذا إلى القول بعدم الفرق بين حقيقة

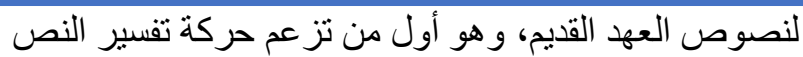
المقد، إذ لم يرض بالمعنى الحرفي فتعداه إلى المعنى المجازي، ذلك أن الكتاب المقس يشتمل على كتابة مليئة بالرموز، تلك الكتابة التي تحوي على وسائط مجازية حيث الهوة واللامعقول و الغرابة أو الضلال الحرفي التي لا يمكن أن تكون إلا إذا أرادها مؤلف الكتابة المقدة، ل (بارة،

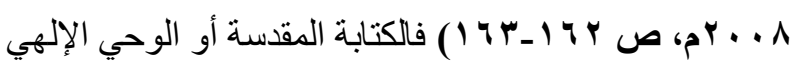
لا يمكن أن تكون بسيطة ومباثرة بوصفها صادرة عن ذات

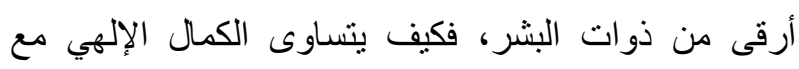
النقصان البشري، وهذا ما دفع رجال الدين إلى إقناع الناس لإسي

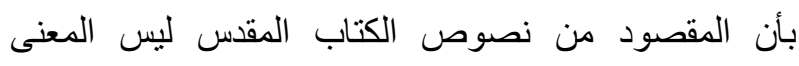
الحرفي، إنما المعنى المجازي الذي يستعصى الوصول إليه

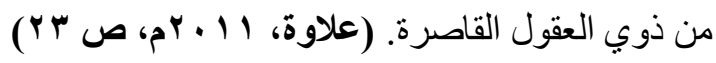
كان فيلون يؤمن بالأفكار الأفلاطونية التي كانت

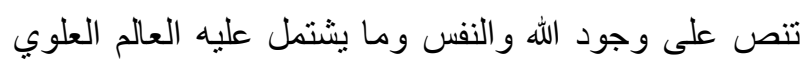

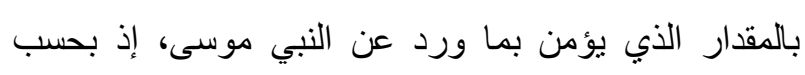

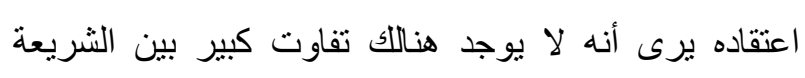

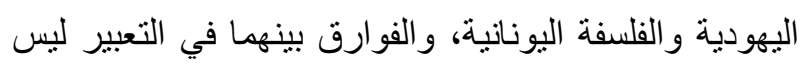

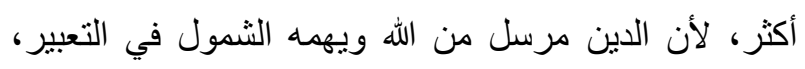
بينما الفلسفة تمثل نتاج أفكار عقلية تبحث في دقائق الأمور

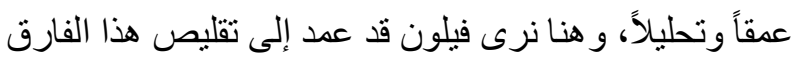
فتوجه نحو فكرة التأويل الرمزي للموضوعات الونات الواردة في

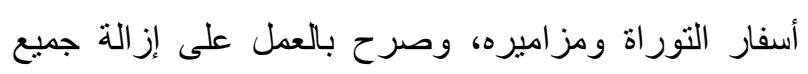

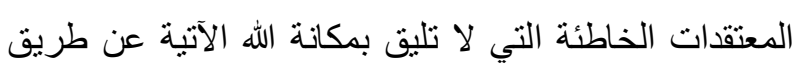

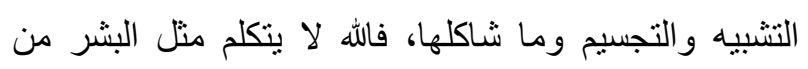
خلال أحرف ولا تخرج عنه أصوات ولا يمكن أن يعتريه غضب، لذلك يرى فيلون أن عملية التأويل الرمزي ذات فائدة كبيرة لكي تسهل علينا عملية الفهم لأية مسألة تكون خارج

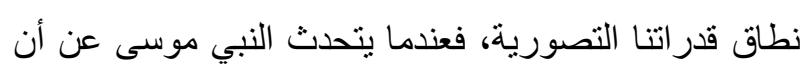
الله قد خلق الكون في ستة أيام، فإن هذا لا يعني أن الله يحتاج

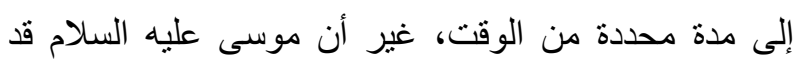

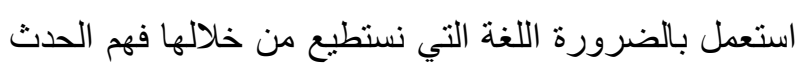

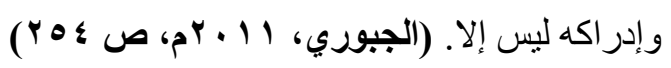
وبحكم طبيعة فيلون الميّلة إلى التجريد والتأمل والاعتز ال نجده يقترب من المثالية الأفلاطونية المحدثة، وفي 


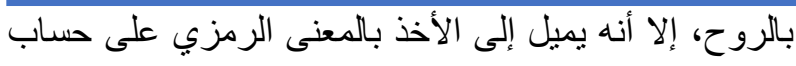

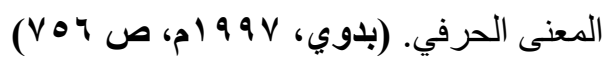

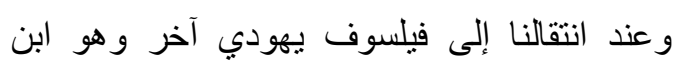
ميمون^ نجده يفسر الألفاظ الواردة في التوراة والكتب الدينية اليهودية المتعلقة بالله بطريقة هرمنيوطيقية، فمثناً حين يتحدث عن تفسير ما في سفر التكوين عن خلق الله الإنسان على صورته حين يذكر الله بأننا نخلق آدم على صورتنا، فالمراد هنا بالصورة الصورة النوعية التي تمثل الإدراك

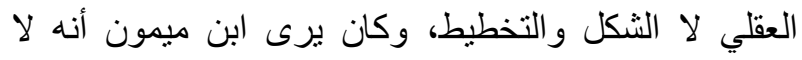
ينبغي تفسير الكتب الخمسة الأولى من العهد القديم تفسيراً لغوياً بحتاً، بل يفترض بنا أن نبحث عن المفهوم التمثيلي كلما بدا تعارض بين المعنى اللفظي وبين العقل، (روشن،

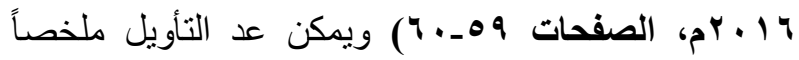
شاملاً لمنهج ابن ميمون في التعامل مع النصوص المقدسة لدى اليهود، ويذكر ابن ميمون أنه سيوفي بعهذ قطعه في شرح المشنا، وأنه سيسعى لثرح المعاني الغامضة الغريبة في كتاب النبوة، وقد سمى تلك المعاني كلها بمشكلات التأويلات، فهو يؤكد على وجوب التأويل لفهم المجاز ات التي يقصد بها ألفاظ الأنبياء التي قالوا بها والتي تحمل معاني

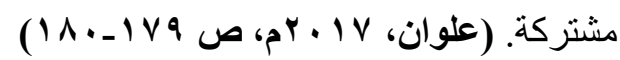
و على الرغم من أن ابن ميمون قد اعتمد على منهج التأويل

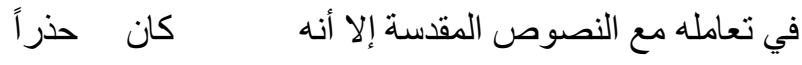
متتبهاً لخطوته هذه متهيباً من هذا الطريق، ومن أجل ذلك فهو الطه

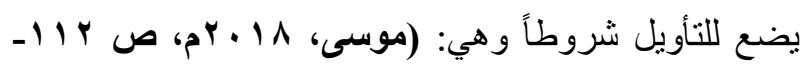

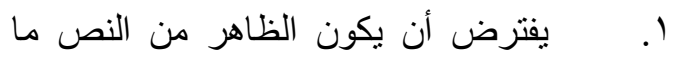

$$
\text { يرشد المتأمل بعقله على المعنى الخفي. }
$$

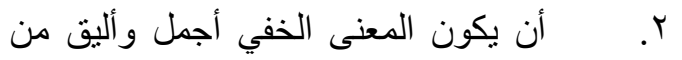

المعنى الذي يدل عليه النص الظاهري.

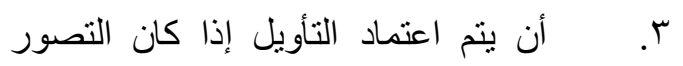

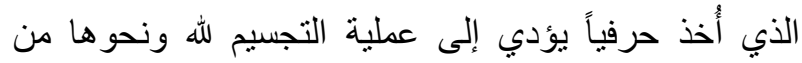

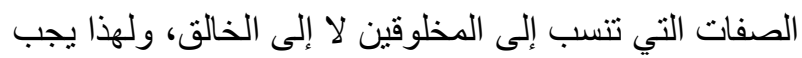

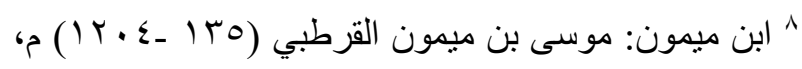
فيلسوف ومن أبرز علماء التور اة في العصور الوسطى.
الفلسفة اليونانية وحقيقة النص المقس. (جاسبر، V... Yم،

(

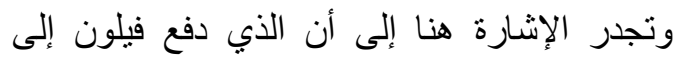

اتخاذ هذا المنهج هو الحملة التي انتهجهارجال الفكر اليوناني على ما في العهد القديم من حكايات غير معقولة، ما أدى

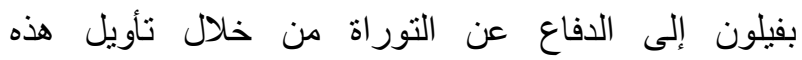
الموضوعات الأسطورية وغير المعقولة الواردة في التوراة تأويلاً رمزياً باطنياً؛ ليظهر للحضارة الإغريقية وجود التفكير العقلاني والوضوح في الكتاب المقدس، وفي عموم التفكير اليهودي، ويرى أن هذا المنهج يمثل روح النص المقدس، ولي

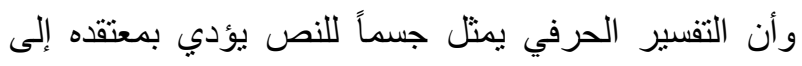
الكفر، فهو يؤول مثناً الجنة بأنها ملكوت الروح، والأنهار الأربعة في الجنة بأنها الفضائل الأربع الأصيلة، و هابيل يعبر عن التقوى الخالصة من الثقافة العقلية، وقابيل يمثل الثخص لهص الأناني، وشيث بمثل الفضيلة المزودة بالحكمة، وأخنوخ يعبر عن الرجاء، وسارة تمثل الفضيلة والحكمة، ويوسف يمثل بهل أنموذج الرجل السياسي، و إذا نم ذكر الثجرة فإنها نوحي بدلالة تتجاوز الإطار الحسي لتدل على مدلول أبعد غوراً، فالثجرة تدل على المعرفة والحياة، فالهرمنيوطيقا المتمثلة عند فيلون بالتأويل الرمزي تذهب إلى ما وراء الحرف

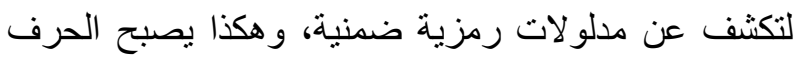
والمعنى عند فيلون على غرار الجسد والروح، ويسعى التأويل الرمزي إلى اختراق حجب الدال ليبلغ المدلول غير المرئي، وهو ممارسة ونشاط ليس في متناول الجميع، إنما يقتضي السلوك الروحي للتحكم فيه والأخذ بزمامه، ويسلم

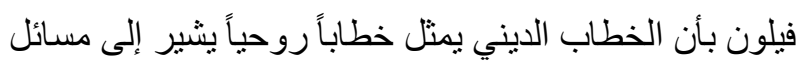
خفية وعوالم غريبة ومفارقة وأسرار باطنية، وأن التأويل الرمزي وحده القادر على فلك عقده، فالكتب السماوية موجهة بتعاليمها إلى جميع الناس العامة منها و الخاصة، ولهذا فهي

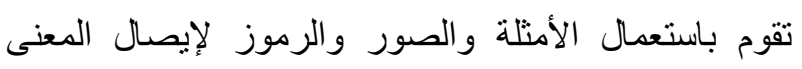
للناس؛ مما يجعل وجود اختلاف في فهم هذه النصوص بين من يأخذ بالظاهر وهم العامة، ومن يأخذ بالباطن وهو هود هوه الخاصة؛ وهذا ما يجعل التأويل ضروري لفهر حقيقة النصوص، و هو يثبه النص بالجسم والمعنى الرمزي 


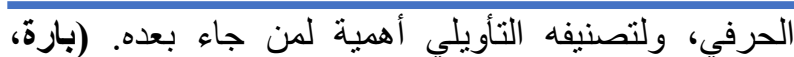

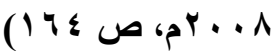

إن مسألة انبثاق العهد الجديد سلطت الضوء على السؤال الهرمنيوطيقي في المجتمع المسيحي بصورة أكثر إثارة، و لاني سيما في ظل التهديد الذي شكلته المذاهب الغنوصية وتفسير ها الخاص على الحركة المسيحية، وقام علماء اللاهوت المسيحيون بالتركيز على تأسيس قائمة بالأسفار ومحاولة

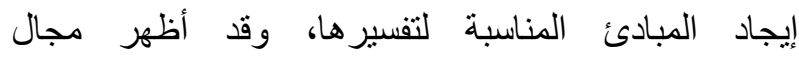
الاستر اتيجيات التفسيرية المتبعة من لان المفكرين المسيحيين الاختيار ات نفسها التي سبق وأن تم تطبيقها في الهرمنيوطيقا اليهودية، و السؤال الحاسم فيما يخص المفكرين المسيحيين كما في الهرمنيوطيقا اليهودية ـ كان يدور حول اتباع منهج حرفي أو رمزي في التفسير، وهكذا فإن التنافس المتزايد بين اليهود و المفكرين المسيحيين لم يؤثر في تناول مبادئ الهرمنيوطيقا، و على العكس من ذلك نجد أن اثتتين من أهم مدارس التفسير واللاهوت في المسيحية المنمنلة بمدرسة أنطاكية ومدرسة الإسكندرية، وقد انتهجت المدرسة الأولى فلى الأسلوب النحوي، في حين انتهجت المدرسة الثانية الأسلوب الرمزي، وكلتا المدرستين يلاحظ وجود ميول هرمنيوطيقية فيهما ترجع إلى موروثات يهودية محلية في الهرمنيوطيقا.

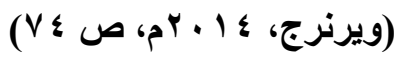
وحين نتصفح تاريخ الفلاسفة واللاهوتيين المسيحيين نجد

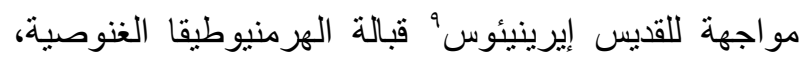
وإن إظهار الغنوصية المسيحية على أسس هرمنيوطيقية خالصة لم يكن ممكناً، وإن كلاً من الغنوصية الز ائفة المتمنلة بالغنوصية الأدرية - بحسب إيرينيئوس - و الغنوصية الحقة المتمنلة بالأرثوذوكسية المسيحية عملتا على توظيف التفسير الرمزي للكتاب المقس مع وجود اختلاف بالنتائج، ومن هنا نعلم أن إيرينيئوس قد شعر بالحاجة إلى استكمال مطلبه الهرمنيوطيقي في تفسير مناسب بمعيار كنائسي، وفي حال

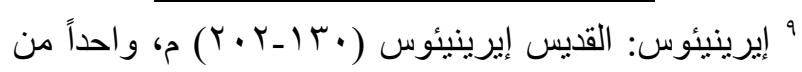
أبرز آباء الكنسية الأوائل ومن المدافعين البارزين عن العقيدة المسيحية، وقد كانت كتاباته تمثل الجانب التقويمي خلال مرحلة بداية انتشار علم اللاهوت المسيحي ونموه.

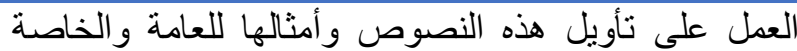

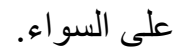

ع. أن نجري عملية التأويل منى ما قام الدليل

العقلي على بطلان المعنى الذي يؤخذ من ظاهر النص، ولهذا السبب تم الابتعاد عن النصوص التي تتهد بظو اهر ها لحدوث العالم مع إمكانية تأويلها؛ لعدم وجود دليل قاطع على قدمه حتى من أرسطو طاليس. ○ أن لا نصل بسبب التأويل إلى معنى يعمل على هدم أي أساس من أسس الثريعة؛ لذلك تم إيجاد سبب ثانٍ في عدم تأويل النصوص التي تشهد بظاهرها لحدوث العالم أن القول بقدمه ـ كما يرى أرسطو - يستأصل الدين من أساسه، ويعد كل المعجز ات بكونها أكاذيب.

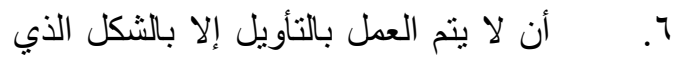

يكفي لفهمه، وأن يكون ذلك للمستعد له فحسب. من ضمن تأويلات ابن ميمون إعطاء معانٍ رمزية لبعض الألفاظ الواردة في النصوص المقدة مثل "الكرسي" الذي يذل على قدرة الله وعظمته، وليس المقصود به أن لله

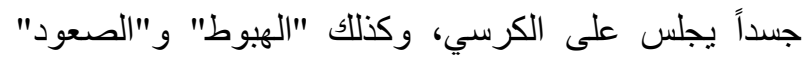
فهي لا تعني أن الله يصعد ويهيط كبعض مخلوقاته، فالله ثابت وليس متحركاً كالمخلوقات، وقد وضع لكل معنى ظاهري يوحي بالتجسيم معنى رمزي يدل على أمر مختلف، والأمثلة

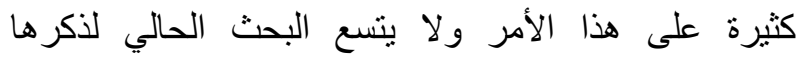

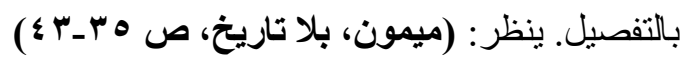

\section{الهرمنيوطيقا والعها الجديد:}

ومع العهد الجديد وظهور المسيحية انبثق وضع جديد تمثل في تطور الهرمنيوطيقا عبر إعادة تفسير النص المقدس في ضوء مجيء المسيح، ومن أهم أعلام المسيحية في بدايتها كان القديس بولس الذي أصر على التأويل المجازي، وزاد الهوة اتساعاً بينه وبين المعنى الحرفي، وقد قدم التأويل المجازي كرؤية تأويلية جديدة تقدم الحل المخلص لقضية تفسير النصوص المقدسة، إذ عمل على تأويل العهد القديم كتجسيد مسبق للعهد الجديد الذي يظهر فيه المسيح، وتأويل القانون على ضوء الإيمان، والحاضر من خلال الأمل الأخروي في مملكة الرب المستقبلية، لذا نصل إلى نتيجة إلى الى أنه مع بولس عرف المعنى المجازي سيطرة على المعنى 
وما تلاه بعد ذلك من تطوير لنظرية التفسير المسيحية بشكل

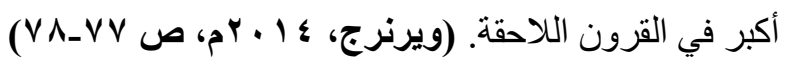

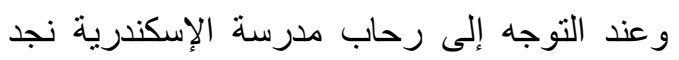

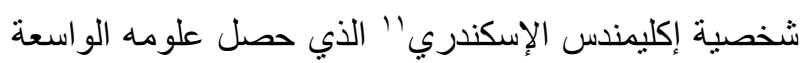
على يد أساتذة من مختلف المناطق في شرقي البحر المتوسط من يونانيين ويهود معاً، وعلى الرغم من أن وجهة نظر إكليمنس كانت تصب في إطار أن يكون تفسير النص منطابقاً مع التقليد الصحيح لتعاليم تلامذة المسيح من أمثنال بطرس وبولس ويوحنا، إلا أنه كان في الوقت نفسه منأثر اً بالمفكر والمفسر اليهودي فيلون الإسكندري الذي قرأ التور اة بعيون الفلاسفة البونان الذي غالباً ما كان يرى أنه يجب الإسب

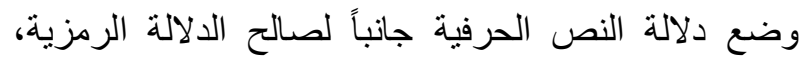
وكان يعتقد بأن النص لا يتضمن معنى واحداً ولكن عدة معان، وكان إكليمنس بسعى إلى التوفيق بين النظريات الأفلاطونية والفلسفة اليونانية من جهة وبين المعتى المتقدات المسيحية التقليدية من جهة ثنانية، وكان يعتقد أن الكتاب المقس بعهديه القديم والجديد يمثل المصدر الأرفع للمعرفة، تئليه و هو بتقديمه لهذه الفكرة يستعين بالمفهوم التمثيلي ليجد أصلاً للحقائق الفلسفية العميقة في حكايات الإنجيل وأحكامه، كذلك بلك بهاه نجد أن فيلون قد كان قريباً من قراءات الأحبار اليهود الذي رأوا أن كل حرف من النص الإلهي المقس لله نميز خاص ومليء بالمعاني العميقة؛ لذلك نجد إكليمندس قد وصف لغة النص الديني بكونها رمزية ويجب أن تفهم بطريقة رمزية

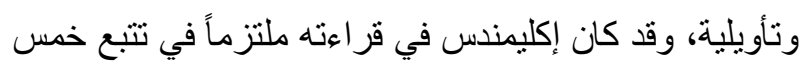
دلالات للنص الديني هي: التاريخي، اللاهوتي، العقيدي، النبوئي والفلسفي، الصوفي، وفوق كل شيء فقد كان إكليمندس مرتماً باللاهوت وبالرؤى اللاهوتية التي يوفر لهاء وفئ الإنجيل خريطة أو مصادر يستقي منها بحرية ما ييني به

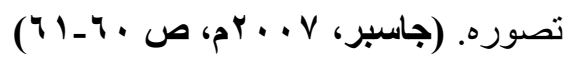

"' إكليمندس الإسكندري: تيتوس فلافيوس إكليمند (10. -

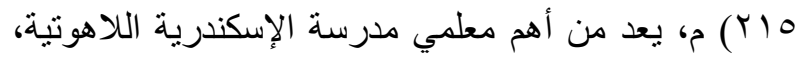
وأكثر ما تميزت به تعاليمه هو توفيقه بين الفلسفة اليونانية و اللاهوت المسيحي، وكانت كل كتاباته بشكل عام موجهة للعالم الهيليني والثقافة اليونانية.
كان المفسر يتمانشى في عمله مع الكنيسة التي تكون بدور ها لألهات جزءاً من الموروث البابوي؛ فإنه سيطمئن إلى أنه سوف يفسر النص على وفق العرف المسيحي المقبول، وأطلق إيرينيئوس على هذا العرف تسمية "لائحة أسفار الحق" الذي ينفرد بتمثيله الموروث البابوي الكنسي، وبحسب رأي إيرينيئوس فإن المخول الوحيد الذي من حقه تقديم الإطار الضروري لتفسير مسيحي أصيل هم مجموعة من المفسرين المسيحيين الشرعيين، وبينما كان إيرينيئوس مشغولاً في إبطال التأويل الغنوصي عن طريق جدل منصل بفهم النصوص المقدة نفسها، فان المفكر المسيحي نرتليان.' استبعد بشكل نهائي فائدة أب تأويل غير مسيحي للكتاب المقس لا بمكن أن يوجد أي تفسير حقيقي خارج نطاق الكنيسة، فضلاً عن ذللك نجده قد صرح بأن الكتاب المقدس يمثل ملكية حصرية للكنبسة، ومن ثم فإن أصحاب المذهب بله الغنوصي لا يملكون الحق في تفسير الكتاب المقس من الأساس، وهنا لم تعد وظيفة المعيار الكنائسي تكميلية، إنما أضحت أساساً للتمييز بين التأويل الأصيل وغير الأصيل.

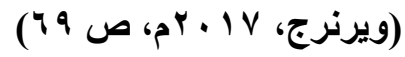
وللتعرف على المدرستين الفكريتين في التاريخ المسيحي اللتان اعتمدتا إطارين نظريين مختلفين في الهرمنيوطيقا تجاه مسألة تفسير النص المقد، نجد أن أصحاب مدرسة الإسكندرية عملوا على كثف المعنى الروحي للنص من منظور معرفة لاهوتية إجمالية، في حين أن أصحاب مدرسة الإسكا

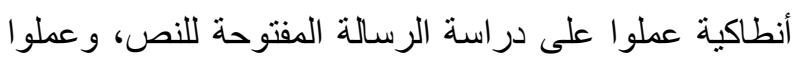
على تقييم الخاصية الروحية للنص بشكل حرفي، علماً أن كلتا المدرستين لم تطبق المنهجية المميزة لكل منهما بشكل مطلق على النصوص المقدسة في بداية أمرهما، إلا أن الموقفين الهرمنيوطيقيين لكلا المدرستين يدلان على القطبين الفكريين الذي امتاز به كل منهما بعد الهرمنيوطيقا اليهودية واليونانية

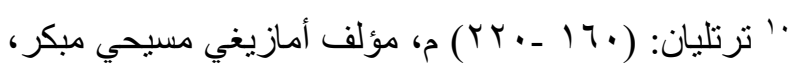
أول من كتب كتابات مسيحية باللغة اللاتينية، كان مهتماً

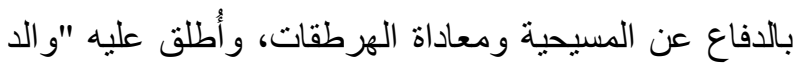
المسيحية اللاتينية" و "مؤسس اللاهوت الغربي". 


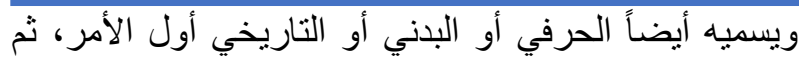
يليه المعنى النفسي، وأخير اً المعنى الروحاني أو الرمزي أو الصوفي، ويضع أوريجانوس تعريفاً بهذه المعاني الثلاثة ترنيمة خاصة للندرج الروحاني كغاية لتحقيق هذه المعاني وبلورتها، فأما المعنى الجسدي فله وظيفة سوق أو توجيه الناس الاعتياديين حتى يتسنى لهم الارتقاء بذواتهم روحياً،

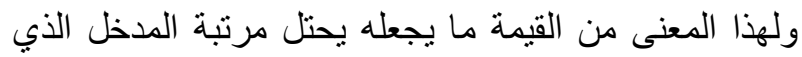
يلج منه كل مخلص باحث عن الحقيقة العقدية، وأما المعنى لهى النفسي فهو يتوجه إلى أولئلك الذين تقدموا أصلاً في المعرفة

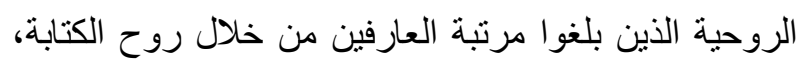
وهم فقط دون غيرهم الذين بلغوا درجة الكمال وحققو ا مبدأ الوصول كما هو معروف في مفهوم التدرج الروحي، ومن ثم الالتحاق والولوج إلى المرتبة الثالثة في المعنى ونقصد بـ المعنى الروحاني الذي أظهر ما لا يمكن تصوره من أسرار الوحي التي أخفتها الحكمة الإلهية وراء المعنى الحرفي.

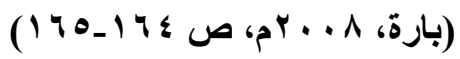
هكذا استطاع أوريجانوس ممارسة التأويل المجازي التصنيفي في العهد الجديد نفسه ما دام أن هذا الأخير بدوره

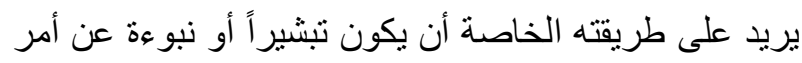
مستقبلي، "نبوءة عودة المسيح"، هذه الفكرة أي فكرة انتظار العود الجديد للمنقذ أو المخلص الني تكاد تكون أساس الفهم العقدي عند الجيل الأول من رجال الدين المسيحيين، وعليه فقد كان من النتائج التي وصل إليها أوريجانوس في المحصلة أنه إذا كان العهد القديم لا يمكن أن يكون إلا أنموذجاً للعهد الجديد؛ فإن هذا الأخير بدوره يجب أن يدرك كرمز للإنجيل

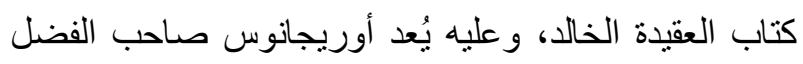
من خلال ابتكاره للمعاني الثلاثة في نسج الخيوط الأولى لمانى للعقيدة الثهيرة المتأخرة عقيدة معاني الكتاب الأربعة بوصفها أبرز إنجاز استفادت منه الهرمنيوطيقا في العصر الوسيط،

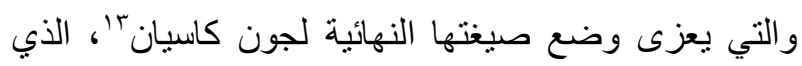
يعتقد بأنه يمكن أن تشتمل الكتابة المقدسة على أربعة دلالات

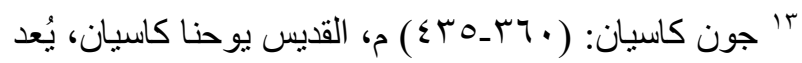
أحد مشاهير الكُتَّاب الروحيين في القرن الخامس و لا سيما في

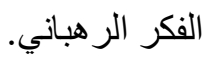

وعلى الرغم من أن إكليمند قد تحدث عن أن الكتاب المقس مكتوب بلغة غامضة ومن ثم نحتاج إلى التعاطي معه بطريقة التفسير الرمزي، لكنه لم يقدم رؤية ذات نسق لمنهج مماتل، وكان أول من قام بهذه المهمة التنظيمية هو لهوبه أوريجانوس'، إذ كان فكره الهرمنيوطيقي قد عمل على لى لى تشكيل منهجه التفسيري، ويُعد الكتاب المقدس - بحسب اعتقاده ــ قد جاء بوحي من الله، ويرى بأن تحقيق نبوءات إسر ائيل في شخص المسيح هو الإثبات الواضح لهذا الوحي، ونقطة البداية هذه تستوجب القيام بتفسير رمزي عند القيام بقراءة نصوص الكتاب المقس، وعلى الرغم من انشغال أوريجانوس بنقد النصوص من أجل تهيئة نسخة نقدية يمكن التعويل عليها من النصوص المقدة ومن ثم تكون ممكنة التفسير بطريقة لاهوتية، فان النقطة الحاسمة في دراسته هي بروز المعنى الروحاني للنص، ويشتمل الكتاب المقدس ـــن وجهة نظره ـ على السر الأقصى الذي لا نستطيع أن نعبر عنه إلا من خلال الرموز، ولا يمكن فهم تللك الرموز بطريقة صحيحة لو تم أخذها بشكل حرفي، ومن ثم فإن المنهج الرمزي هو وحده الكفيل بأن يزودنا بالمفتاح المطلوب لفك لك السر المستودع داخل النص، ونظرياً قام أوريجانوس بتمييز بنية ثلاثية للمعنى النصي هي: الحرفي والأخلاقي والروحاني، لكننا في التطبيق نجده قد ميز بين الحرفي و الروحي فقط، كما أنه شارك إيرينيئوس في كونه اعترف بالحاجة في أن يكون المفسر موجهاً من لدن الكنيسة.

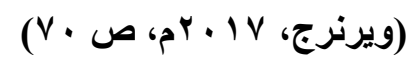

تكمن قيمة نظرية أوريجانوس للمعاني الثناثة في الكتابة المقدة في كونها ستهيئ التربة لما سيأتي فيما بعد من القرون للعقيدة المتأخرة المعروفة بمعاني الكتاب الأربعة، فمفتاح تأويل التور اة بحسب أوريجانوس يكمن في إعادة كتابة النص المقدس ثلاث مرات حتى يتسنى الوصول إلى حقيقته، هذه القاعدة تعني أنه على الثارح لهذا النص نفسه أن يعيد كتابة معنى النص ثلاث مرات في روحه: المعنى الجسدي نعاه

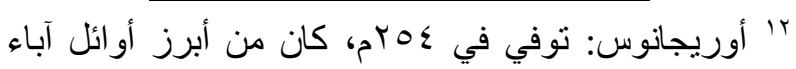

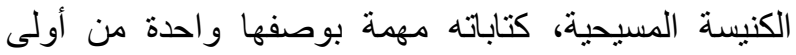
المحاو لات الفكرية لوصف المسيحية. 


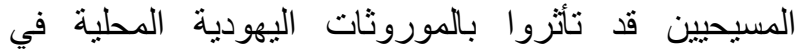
التفسير، وقدموا نظرية في تفسير الكتاب المقس كان اهتمامها منصباً بالأساس في مسألة التفسير الحرفي، ومن ثم

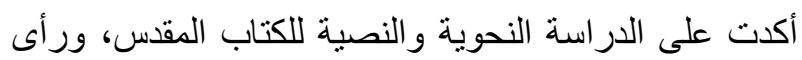
ثيودور المصيصي \&' المخاطر الناجمة عن الهرمنيوطيقا التي والي نادى بها أوريجانوس من خلال تجاهل مدرسة الإسكندرية

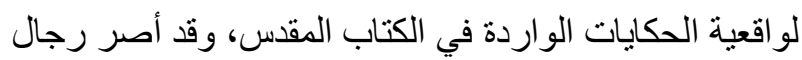
مدرسة أنطاكية على موضوع الحقيقة التاريخية للوحي، ولم تكن لهم رغبة في التخلي عن هذه الحقيقة التاريخية في عالم من الرموز والظلال، وكانوا يميلون إلى المنهج الأرسطي هن هي أكثر من المنهج الأفلاطوني، وفي الوقت الذي استعمل فيه أصحاب مدرسة الإسكندرية كلمة "نظرية" كمعادل للتفسير الرمزي، فإن المفسرين من مدرسة أنطاكية قد استعملوا

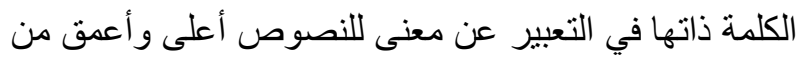
المعاني الحرفية أو التاريخية، لكنه مبني بقوة على الحرف، وقد رفضوا وجود معنى باطني في نصوص الكتاب المقدس،

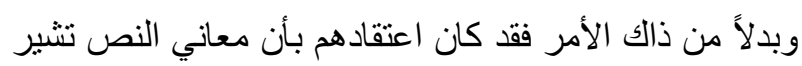
إلى وقائع فعلية مفهومة وواضحة لكل قارئ يهتم بالبحث، لذلك فإن النبوءات اليهودية لا تشتمل على إشارة رمزية بل و اقعية إلى المسيح، وحديث النبي يكون مليئاً بمصطلحات حقيقية وبوعي عن مجيء المسيح، وبناءً على هذه القراءة الحرفية لنصوص لكتاب المقد فإن رجال اللاهوت الأنطاكيون قد عمدوا إلى إعادة دراسة النصوص؛ لأجل التثبت من تللك النصوص التي الوحي الإلهي، وتللك المغايرة لهذا الأمر؛ لغرض استبعادها من قائمة الأسفار المسيحية للكتاب المقد، وإن أي غياب يتم تشخيصه لأي مرجعية

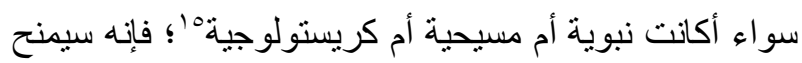

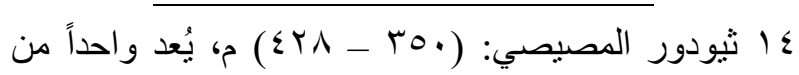
أشهر ممثلي مدرسة أنطاكيا، وأبرز معلمي كنيسة المشرق على مسنوى اللاهوت وتفسير الكتاب المقدس. 10 كريستولوجية: مجال دراسة ضمن اللاهوت المسيحي مهتم بدراسة طبيعة يسوع، ولا سيما كيفية ارتباط الألوهية و الإنسانية في شخص يسوع.
مقصودة من لدن الرب هي: المعنى الحرفي، والمعنى المجازي، و والمعنى الأخلاقي، و والمعنى الباطني، و هذه النظرية نؤسس لفهم النص المقدس من منظور ات أربعة هي: المعنى الحرفي الذي يُدرك بالتأويل النحوي، والمعنى المجازي المعني بترجمة تعاليم الكنيسة وقواعد الاعتقاد المسيحي، والمعنى الأخلاقي المخصص لتوجيه المؤمن المسيحي وتهذيب سلوكه، والمعنى الباطني الذي يفتح للمسيحي باب الولوج إلى العالم الأخروي، ويصله بالأسرار

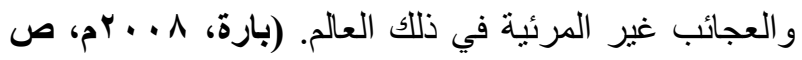

(17V-197 مما سبق نفهم أن أوريجانوس يميز بين عالمين، عالم واقعي ظاهري وعالم روحي عرفاني، وتبعاً لذلك فالكون مليء بالرموز، وأنواع العالم غير المرئي التي لا تدرك إلا من

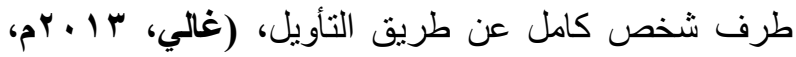

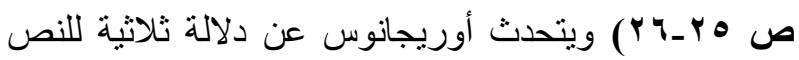
المقس المتمثلة بالمعنى الحرفي والمعنى النفسي والمعنى

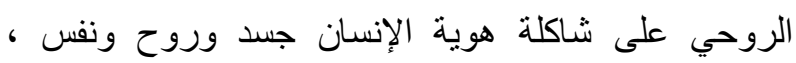

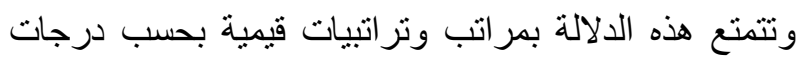
الناس واستيعابهم العقلي، فالمعنى الحرفي يكون خاصاً بالعوام، وأما المعنى النفسي فيكون للخواص، في حين يكون المعنى الروحي مخصصاً لخاصة الخواص، وأن الطبقات الخاصة بالمعنى والمُشكلة للنص المقس تسمح بأن يخترق القشر الظاهر لكي يصل إلى اللب الباطن، و هذه النمطية التي بالي

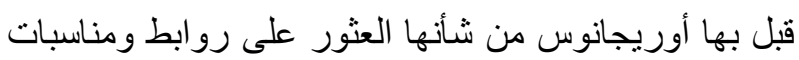
بين العهد القديم والعهد الجديد، فهو يعتقد أن النص ينطوي على معنيين مرتبطين، معنى حرفي يدعمه ويسمو به إلى لي

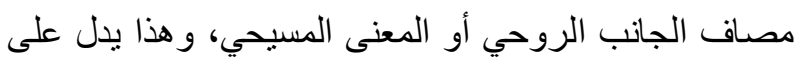
أن كل حرف من حروف النص المقدس يشتمل على حقائق وأسرار تُعرف من خلال مفاتيح التأويل الرمزي والنمطي، فالحرف يمثل الحامل لسر الروح و المعنى، كذلك الحرف في النص المقدس يمثل الحامل لروح الإله، ولا يتم الارنباط بهذه الروح إلا من خلال فلك الارتباط عن المحسوس. (الزين،

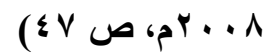
وإذا أردنا الانتقال إلى المدرسة الفكرية المقابلة لمدرسة الإسكندرية المتمثلة بمدرسة أنطاكية نجد أن المفكرين 


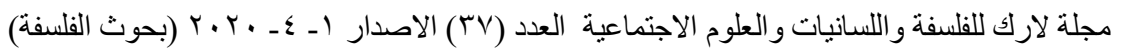

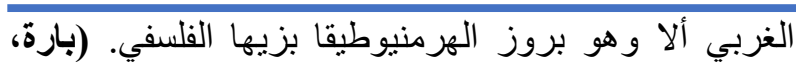

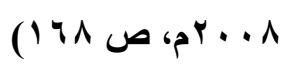

وعند تقليب صفحات تاريخ الهرمنيوطيقا الدينية نقف عند

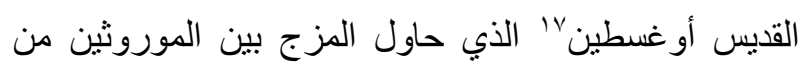
هرمنيوطيقا مدرسة الإسكندرية ومدرسة أنطاكية في تركيبة

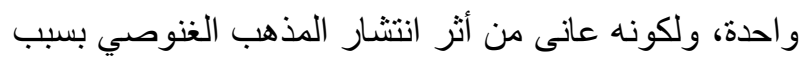
انعدام فائدة التور اة اليهودية، وهذا الانتشار مبني على التهن التفسير الحرفي؛ فقد نَعِم أو غسطين بفسحة من الحرية في اتخاذ منهج

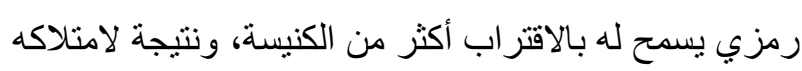
حظاً وافراً من المعرفة في مجال علم البيان فقد كان بملك لكالك

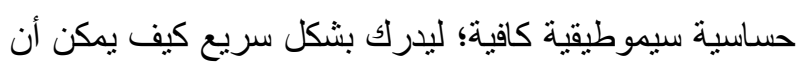

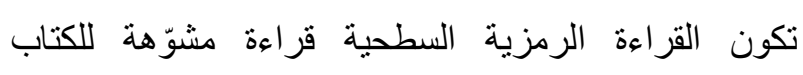
المقس، ونتيجة لهذا الأمر فقد أيّد أوغسطين مسألة وجود

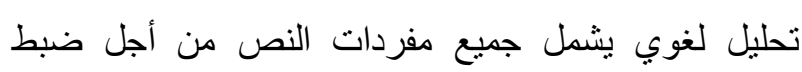

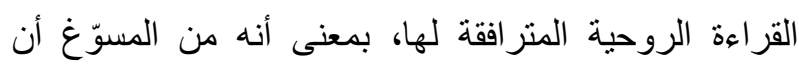

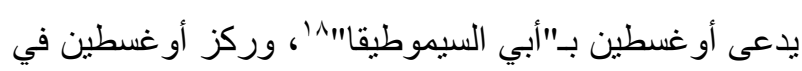
مؤلفه "حول العقيدة المسيحية" حول الهرمنيوطيقا وفن الهن الوعظ، وركز انتباهه على دراسة الوظيفة التواصلية للرمز ، ويستعمل الرمز لكي يشير إلى حقيقة معينة، والرموز لا تمثل

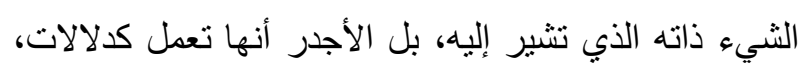

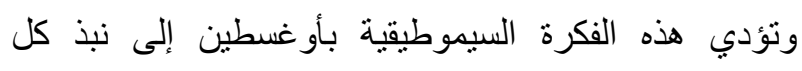
الجهود التي تعمل على تحديد الكتاب المقدس بما تشير إليه

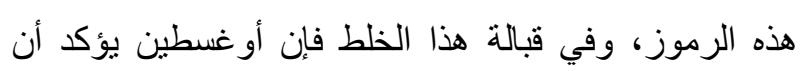
نصوص الكتاب المقدس تمثل نصوصاً بشرية تثير إلى الله،

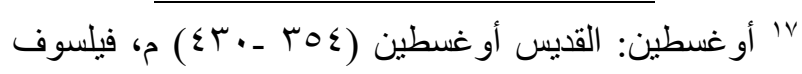
وأحد آباء الكنيسة البارزين، ويُعد واحداً من أهم الثخصيات

$$
\text { المؤثرة في المسيحية الغربية. }
$$

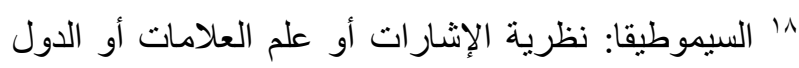

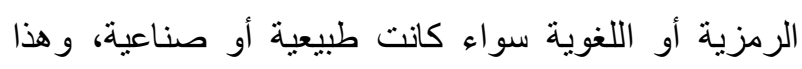

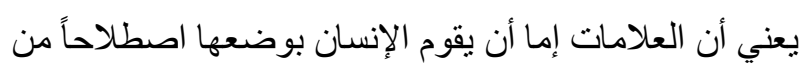
خلال اختراعها والاتفاق مع بقية الناس على دلالاتها

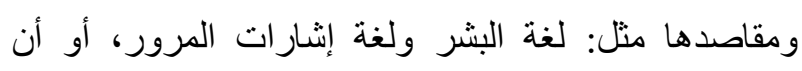
الطبيعة هي التي قامت بفرزها بشكل عفوي وفطري منل

$$
\text { أصوات الحيوانات والعناصر الطبيعة. }
$$

سبباً كافياً لاستبعاد ذلك النص من قائمة أسفار الكتاب

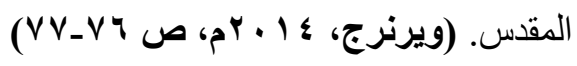
لكن اللافت في كل هذا وذالك أن الدوائر الدينية التي نشأت في كنفها هذه المفاهيم بقيت وفيّة لأجززتها المعرفية وأصولها العقدية، إذ كانت ترفض كل حركة تنويرية أو رؤية تجديد إلا في إطار ما تقره هي نفسها، وقد تبدى ذلك بصورة واضحة

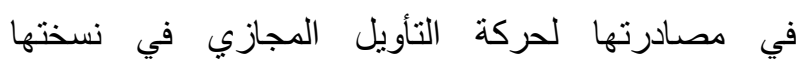
الأوريجانية أو مع مارنن لوثر 17 فيما بعد، إذ عدّت كل تأويل

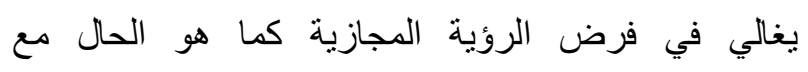

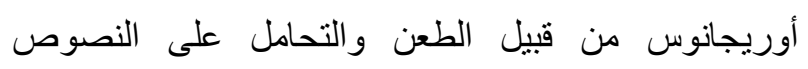
المقدسة التي و إن فتحت باب التأويل المجازي، فإنها قيدت وندي هذه العملية بعدم تجاوز المعنى الحرفي بوصفه أصل المعنى

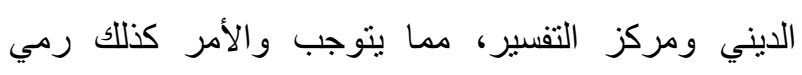

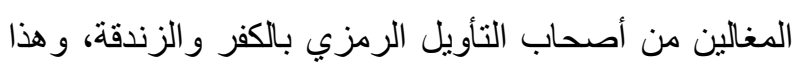
ما جعل التأويل الرمزي يرتبط بفكرة المماتلة ومعه تحديد الهرمنيوطيقا لمفهوم الرمز من منظور المماتلة، كل هذا يؤدي إلى حصر مفهوم الهرمنيوطيقا بجعله مرتبطاً بالتفسير

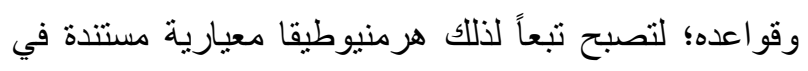
تفسير النصوص إلى مرجعية سلطة ملكية (مجلس كهنة) أو

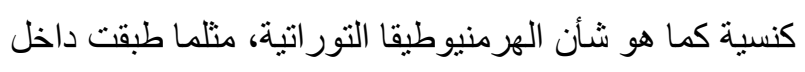

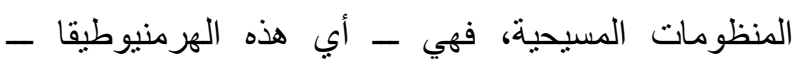
بوصفها كذلك يتعذر استثمارها في تأويل النصوص الأدبية لأنها ببساطة علم يُعنى بتفسير الكتاب المقس، لكن لون ومهما يكن من أمر هذا التحيز المعلن من قبل السلطة الكنسية، فإن لإنهير الذي لا يجب نكر انه هو أنها بما قدمته من آراء و أثنارته من من فئ قضايا ومقو لات بشأن تفسير النص الديني ناهيك عن نظرية معاني الكتابة الأربعة كانت بحق نربة خصبة لمبلاد نظرية

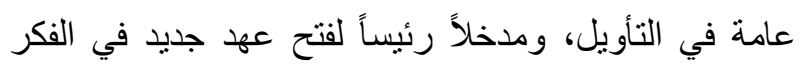

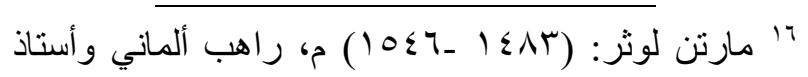
اللاهوت، ور ائد حركة الإصلاح الديني في أوروبا، عمد إلى إنى

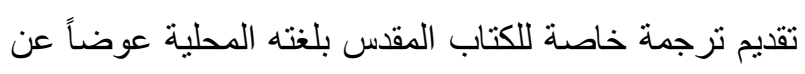
اللغة اللاتينيّة التي كان مسموحاً بها من لان الكنيسة الرومانية باستعمالها لقر اءة الكتاب المقدس. 


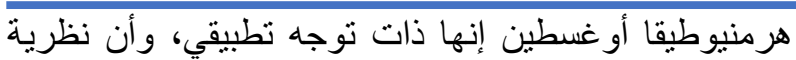
القر اءة عنده ذات التوجه اللاهوتي و التو اصلي المميز تتبع من تأمله في تطبيق السعي المسيحي للمعنى الأقصى، ومما سبق نصل إلى أن هرمنيوطيقا أوغسطين ليست نتيجة للتفكر

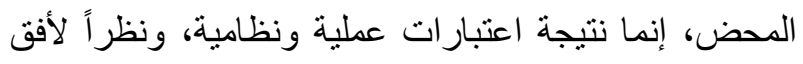

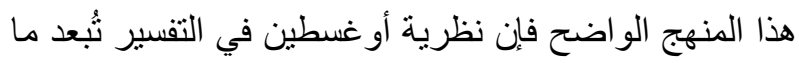
نسميه اليوم بـ"حرفية الكتاب المقدس"، أي موقف تعظيم غير ناقد اتجاه نصوص الكتاب المقدس بناءً على الاعتقاد بالعصمة المطلقة لهذه النصوص، وبحسب رأي أوغسطين فإن الكتاب المقدس موجود من أجلنا ومن أجل هدايتنا، لكنه ليس أمراً جوهرياً أن يتلقى المسيحي الهداية التي بستطيع الكتاب المقس منحها عن طريق مواجهنه الشخصية مع النصوص نفسها، والمهم أن يتوصل التابع المسيحي إلى الخلاص الذي تشير إليه النصوص المقسة، فمن ييني حياته بقوة على الإيمان والحب والأمل؛ فإنه يحتاج إلى الكتاب المقس من أجل تعليم الآخرين، ومن ثم فإننا يمكن أن نجد الكثير من البشر ممن يعيشون على هذا الأساس من دون

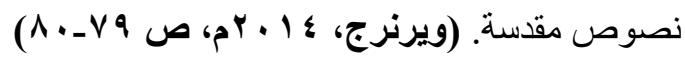
من خلال تتبعنا للأثر الأوغسطيني في شرح النصوص المقدة نجد أن أوغسطين يُعد أهم هرمنيوطيقي في الكنيسة المسيحية الأولى، وقد كان قارئاً جيداً للفلسفة اليونانية والأفلاطونية، وكما فعل أوريجانوس وآخرين قبله فقد سعى ولهى إلى توظيف معرفته بنحو مؤثر في بلورة مبادئه الهرمنيوطيقية، وهذا يعني أن الهرمنيوطيقا المسيحية كانت مزيجاً من تقاليد القراءة والتفسير اليهودية واليونانية، ومثلما فعل أوريجانوس نجد أن أوغسطين قام بتطوير نظام معقد من القراءة الرمزية كالقراءة التي عرضها في الفصل الثنامن من كتابه "الاعتر افات"، إذ عمل على تقديم تفسير رمزي مفصل للفصل الأول من سِفر التكوين، فالظلام ـ على سبيل المثال ـ الذي فصله الله عن النور في التكوين: الاوفصل الله بين النور والظلمةه) (التكوين ؟: (1) يرمز إلى الروح التي ماتز ال

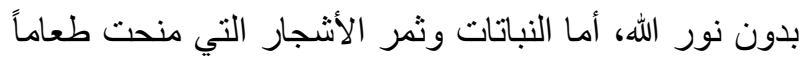

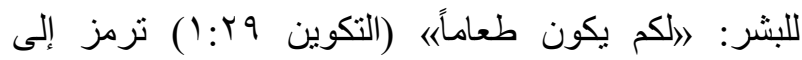
الحسنات التي تنعش وتتمي الروح، وفي الوقت نفسه طور أوغسطين قراهة متعددة للنص الديني إذ لا وجود لنص مقيد
ويفترض أن لا يتم التعامل معها على أنها تمثل الله، بل يجب توظيفها بدلاً من ذلك من لدن القارئ المسيحي لتوجهه في لتمائ اتخاذ الموقف المناسب اتجاه الله، واتجاه أخوته في الإنسانية، واتجاه نفسه، وفي هذا السياق نجد أن أوغسطين يميز بين الأشياء التي نتمتع بها والأشياء التي نوظفها، ويكون التمتع فقط في الأشياء التي تتصف بكونها أبدية لا تتغير، بينما نجد أن صفة التغير في أحسن الأحو ال تكون موجهة للشخص إلى لى لثي الاستمتاع الأصيل بأثنياء أبدية وهكذا، وبما أن الله هو ما لاكوله يمكن التمتع به فقط؛ لذا فإن النصوص أعطيث لنا كي يتم توظيفها من أجل الممارسة الإيمانية، وأن هذا الموقف الضروري لنا من أجل وجود ارتباط مناسب بالله، وشريعة الله المعبر عنها في النصوص المقدة قد تم تحديدها وتسميتها

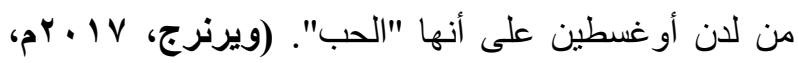
ص v يُعد فهم أوغسطين للمهمة الهرمنيوطيقية فيما يخص القارئ المسيحي تقدماً مهماً عن الجدل بين أصحاب مدرسة الإسكندرية وأصحاب مدرسة أنطاكية بشأن نظرية تفسير مناسبة، فمن جهة يعمل أوغسطين على تقديم إطار سيموطيقي ينظر إلى النص الإنجيلي كما ينظر إلى أي نص لصن بشري آخر في كونه يؤدي وظيفته فيه، لهذا يجب تفسيره

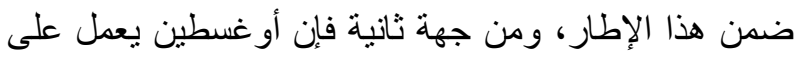
تزويدنا بمنظور للقراءة المتمثل بالحب، المأخوذ من قراءته لنصوص الكتاب المقد، وأن حب الله وأخوتنا من البشر يمثل المنظور الأفضل للقراءة فيما يخص المؤمن المسيحي، وله وله وهذا التركيز الكلي لم يعد يؤخذ من خارج سياق النص المقد، ولكن - بحسب زعم أوغسطين - فإنه يمثل المنظور الوحيد الذي يمكن عن طريقه قراءة قائمة أسفار الكتاب المقد، ويقوم البعد السيموطيقي في نظرية التفسير الخاصة بأو غسطين على تحرير القارئ للنص المقدس من أي حرفية فجّة، ومن أب مخاطر تتعلق بالرمزية العشوائية، كذلك بعمل على تشجيع القارئ في اعتناق منظور قراءة لاهوتي ملقن من لان النصوص المقدسة نفسها، وهكذا نجد أن منظور أوغسطين المقترح للقراءة يصبح مفتوحاً على منى لأل إمكانية التثبت من لدن كل قارئ، ولا يشير بعد ذلك إلى أي

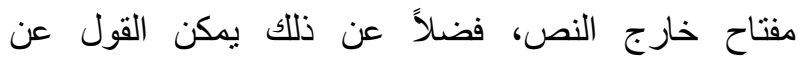




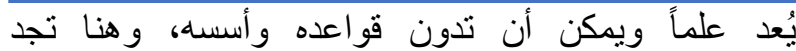
الهرمنيوطيقا ارتباطاً وثيقاً مع البيانات المجازية، ويرى أوغسطين أن لكل مجاز معنى رمزي، وهكا فسر غريغوري" أفي كتابه "الأخلاقيات الكبرى" سِفر أيوب من الكتاب المقد بالاعتماد على منهج أخلاقي خاص ونظرية

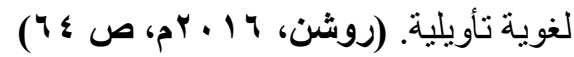
حينما يناقش أو غسطين تفصبلات عملية تفسير النص المقدس نجده يميز بين الرموز الطبيعية ـ مثنال على ذللك ـ الدخان المنبعث من النار وهو ما يدل على وجود النار كمسبب لله، وبين الرموز التقليدية وهو التصنيف الذي تندرج تحته كل الرموز اللغوية، ونتيجة للطبيعة التقليدية للرموز اللغوية جميعها فإنه من المهم لقارئ الكتاب المقدس أن يألف التقاليد اللغوية الخاصة التي تم في سياقها إخراج الكتاب المقدس، ولذلك نجد أن أوغسطين يطالب بوجوب الإلمام بكل من اللغة العبرية و اللغة اليونانية لأي فرد يتصدى لتفسير الكتاب المقدس، وعادة ما يكون سوء الفهم المحتمل الذي يمكن أن ينشأ عن التفسير متصل بإثكاليتين في النصوص، تتمثل الأولى في احتواء النصوص على إشارة مباشرة أو تأديتها لوظيفة مجازية، أما الثانية فتتمثل في أن الرموز يمكن أن أن تبدو غامضة للمفسر أو تكون مجهولة، ومن خلال تناوله لهذه المشكلات نجد أوغسطين يحث القارئ على فهم الرمز في سياقه، وأن يستجلب كل المعرفة المتو افرة لكي تعينه على فهم المقاطع الغامضة في النص المقد، ويمكن حل مشكلة الغموض المحتمل بشأن النص عن طريق السعي في الحصول على إرشادات من الكنيسة، ويمكن للإيمان أن يسلط الضوء على الفقرات المستغلة، وفي حال تعذر هذا الأمر فيمكن للقارئ الحذر في أن يقرر لنفسه، وما أن يحرك الحب القارئ باتجاه الله وباتجاه الجار فإنه من غير الممكن أن يخطئ المعنى الروحي المتضمن في النص المقس.

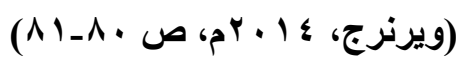

19 غريغوري: البابا غريغوري الأول أو غريغوري العظيم

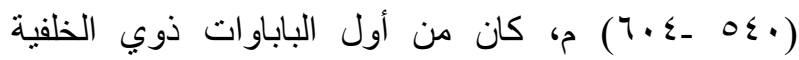

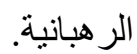

بمعنى واحد، وكان هذا بالطبع محاولة منه لحل الجدل الهرمنيوطيقي القائم بين مدرستي الإسكندرية وأنطاكية، إذ هاذ طور نظرية في التفسير تشمل التفسير الحرفي والرمزي معاً في مؤلفه "حول العقيدة المسيحية"، وقدم أوغسطين مبادئ واضحة للتمبيز بين التفسيرين إلا أنه على وفق أولويات وله الممارسة الروحية يكون الترجيح للتفسير الحرفي، (جاسبر،

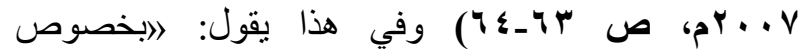
العبارات الرمزية لا بد من لحاظ القاعدة التالية: على القارئ أن يتعامل بحذر مع كل ما يقرأه إلى أن يستقر على القراءة

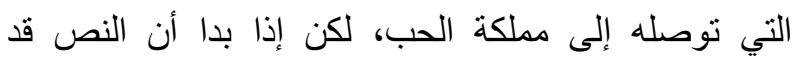
استعمل بمعناه الحرفي فلا يمكن عندها التعامل مع التعبير

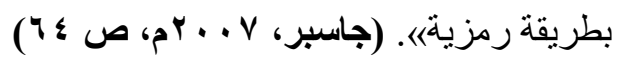
يعتقد أوغسطين أن النصوص المقدسة مرسلة إلى البشر من رجال دين وعلماء وعامة الناس؛ لذا يفترض أن نكون واضحة حتى يتمكن الجميع من فهمها، وقد تميز عمّن سبقه بوضع حد للإبهام الذي يتعدد البعض وسم الكتابة المقدة بها، وكأن الأمر يتعلق في المقاربة الهرمنيوطيقية بالبحث

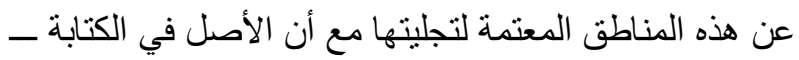
بحسب أوغطين - هو الوضوح، الأمر الذي يجعلها في متناول جميع شرائح المجتمع، ويتساءل أوغسطين كيف برسالة إلهية موجهة إلى عامة الناس أن تكون مبهمة و غامضة والأولى بها أن تكون واضحة كي يستطيع الجميع

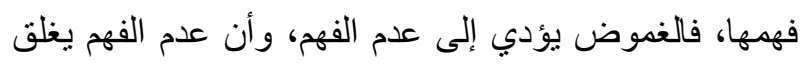
قنوات التو اصل؛ وهذا ما جعل المسيحيين يلجؤون إلى الله من خلال وسائط مثل الكهنة ورجال الدين، الأمر الذي جعل

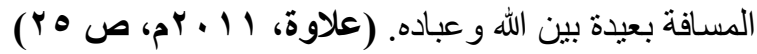
على الرغم من أن أوغسطين كان يعتقد بأن الكتاب المقس كتاب واضح وقابل للفهم، لكنه في الوقت نفسه كان يرى أن الاقتصار على قو اعد التفسير لا يكفي لفهمه، بل لا بد من نور القلب ليرفع الإيهام عن ذلك الكتاب، وهذا النور يُلِهم من الله، وهو يرى أن الخطط بين المعاني الحقيقية والمجازية

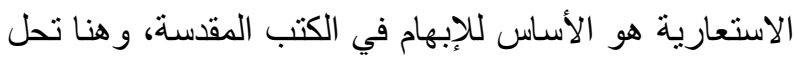
المشكلة بواسطة النور الإلهي في إرجاع المبهمات إلى

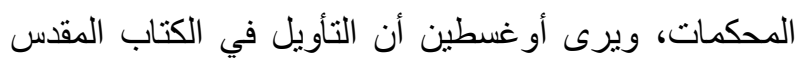
يشرع من التفريق بين الكلمة ومعناها الرمزي، و هذا بحد ذاته 


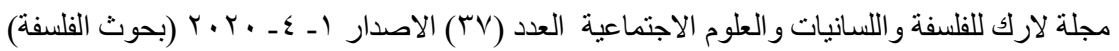

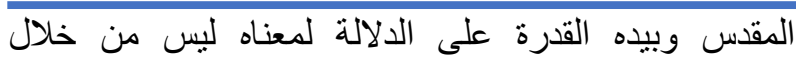

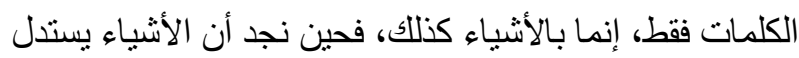
عليها بالكلمات في كل علم، فإن علم اللاهوت لله خاصية

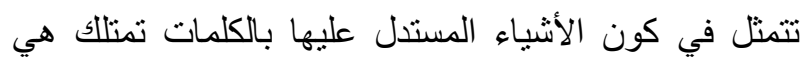

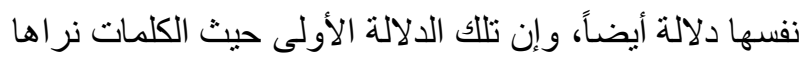
تدل على الأشياء وهنا سنكون إزاء المعنى الأول المتمثل بالمعنى الحرفي، أما تللك الدلالة التي يكون الاستدلال فيها على الأشياء بالكلمات يحمل بحد ذاته دلالة فسنكون حينها إزاء المعنى الروحي المبني على المعنى الحرفي ويفترضده مسبقاً، وعندها سوف لا يحدث أي خلط في الكتاب المقدس لأس إنى

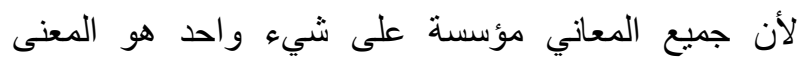
الحرفي، الذي يمكن أن ينشأ أي جدل منه وحده، وليس من هن تلك المعاني الرمزية بحسب ما صرح به أوغسطين، ومع ذللك لا ينتفي شيء من الكتاب المقدس على وفق هذا الكلام فلسنا نجد ما هو مهم للإيمان ينطوي تحت مسمى المعنى

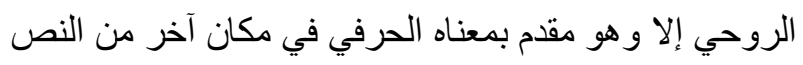
المقس، وبحسب رؤية الأكويني يفترض أن يكون المعنى الحرفي هو ما بسعى إليه أي لاهوتي لأجل بلوغه، وأن تقليل

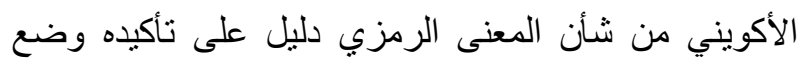
أساس علمي للاهوت، إذ كان من الضروري إعادة بعاد تتظيم التفكير اللاهوتي بشكل يتفق مع الصياغة الجديدة

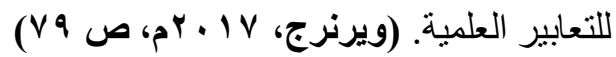
وإن سبب رفض توما الأكويني للتفسير الرمزي هو محاولة

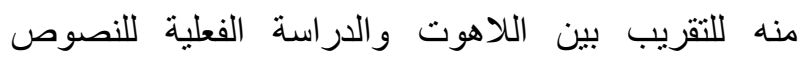
الإنجيلية، غير أن تحوله نحو الفلسفة جعل من التفكير اللاهوتي مستقلاً عن تفسير الإنجيل مرة أخرى، وعلى الرغم

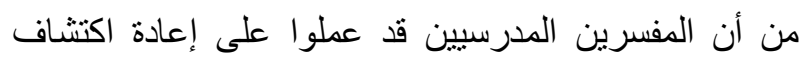
نص الكتاب المقس وحاولوا تناوله بجدية وبذاته، لكن اللاهوت سيطر على اهتمامهر كما كان آباء الكنيسة من قبلهم، ومع ذلك فإن اللاهوت المدرسي نجده مختلفاً كثيراً عن اهن اللاهوت عند السابقين، غير أن اللاهوت بقي مبنياً على الكتاب المقدس، وقد أصبح الغاية الوحيدة من التفسير منمثلة بتهيئة الكتاب المقدس للاهونية التنظيرية، وأصبح يطلق على ملى اللاهوت المحض حينها تسمية "التعاليم المقدة" التي زعمت بكون محتواها ممثلاً للكتاب المقد، لكن التعاليم المقدسة
عمل أوغسطين على تطوير العملية التي كانت

مقتصرة على التمسك بحرفية المعنى أو برمزيته فأضحت عنده بشكل آخر يتمنل بالمعنى الحرفي، و المغزى الأخلاقي،

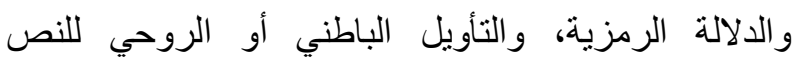
المقس، فالحرفية توضح لنا ماذا فعل الله وماذا فعل آباؤنا، والرمزية توضح لنا أين يختبئ إيماننا، والمعنى الأخلافي يعطينا قو اعد السلوك اليومية، والعرفانية تبين لنا أين ينتهي سعينا، وبهذا يمكننا القول في إن بروز المشروع الأوغسطيني في الفكر الغربي كان بمنزلة الكثف عن مسكوت العقل الغربي وإعادة بعث السؤال من جديد، سؤال

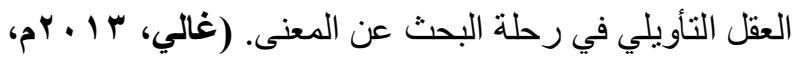
( والقارئ لكتابات أوغسطين يجد نركيزه على فائدة التقوى

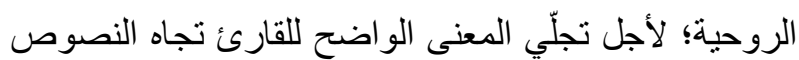
المقدة المبهمة، فضلاً عن تعلم العبرية واليونانية، إذ يقول: 》اإن الإنسان الذي يخشى الإله يبحث بعناية عن إرادته في الكتابات المقدة، التقوى تمنحه الحلاوة وتبعده عن روح الخلاف والجدل، إنه يتجاوز من خلال علم اللغات كل ما يمكن أن يعيقه من المصطلحات والعبارات الغامضة، إنه يستحوذ على المعارف الضرورية المتعلقة بالطبيعة وخصائص الأثباء التي تمكنه من إجراء مقارنات، ومن يكون قد تطهّر من كل خطأ يمكنه أن يبانشر مناقشة وتوضيح

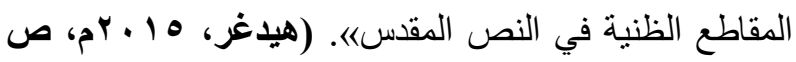

$\left(\leqslant 0_{-} \leqslant \varepsilon\right.$ وعند الانتقال إلى فيلسوف مسيحي آخر مهم ذلك هو القديس

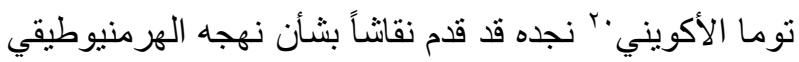
في بداية كتابه "الخلاصة اللاهوتية"، و على الرغم من كونه أكد مبدأ التفسير الرباعي للكتاب المقد، لكنه أعاد تعريف مجال المعنى الحرفي وأهميته، و الله عنده هو من ألّف الكتاب

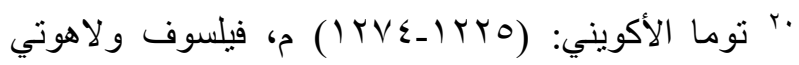
ويعرف بالعالم الملائكي، يُعد إحدى الثخصيات المهمة في مذهب اللاهوت الطبيعي، يعدّه الكثيرون من المسيحيين فيلسوف الكنيسة الأعظم لذلك سميت باسمه الكثير من المؤسسات التعليمية. 


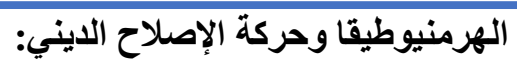

ويطل علينا من ناحية أخرى رائد حركة الإصلاح الديني مارتن لوثر الذي كان له إسهام كبير في تجديد المسألة

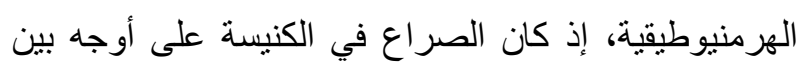
مؤيدي المعنى الحرفي والمعنى المجازي، وقد دعا لوثر إلى لـ إنى الثورة على سلطة التقليد القديم للتفسير، ورلا سيما نظرية

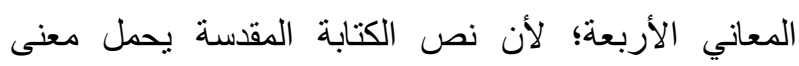
مشتركاً يتمثل بالمعنى الحرفي الذي يفتح المجال واسعاً أمام

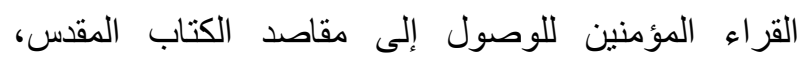
و الوقوف على المعاني الروحانية التي تدرك بصورة و اضحة

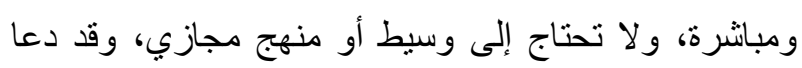

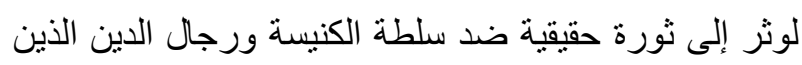
احتكروا فهم النص المقد لأنفسهم، وتحكمو ا في فهم عامة لونة الناس، فكيف يرسل الله رسالة يفهمها بعض الناس ثم يتأولونها على وفق آرائهم ووجهات نظرهم، وبعد ذللك ئل

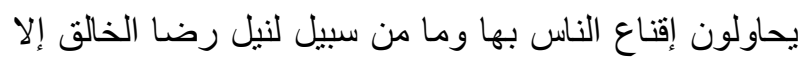
باتباع تأويلاتهم، وكيف يعيش الناس الأحرار ذوو العقول

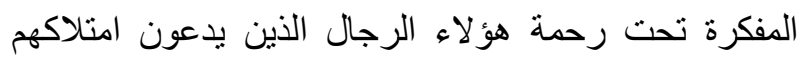

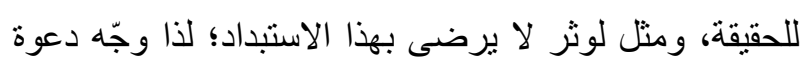
إلى ضرورة تجاوز المعنى المجازي، والتعامل مع المعنى الحرفي الذي يتيح للناس البسطاء فهم هذا النص المقدس ودس المرسل إليهم، وبذلك تصبح الهرمنيوطيقا مع لوثر مرتبطة

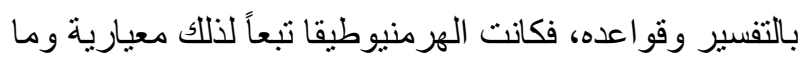

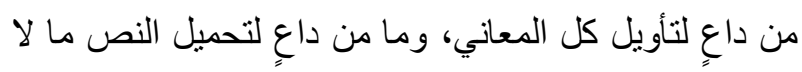
يمكنه تحمله، و لا بد من وضع قو اعد للتفسير، لكن من دون مبالغة في تعقيد المعاني واحتكار ها لدى رجال الكنيسة.

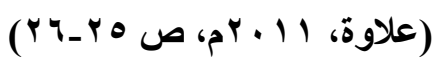
وبفضل الطرح الذي طرحه لوثر ييقى الفهم بوصفه القضية الأساس في الممارسة الهرمنيوطيقية مثار الجدل بين السلطة الكنسية التي تدعي امتلاكها للحقيقة الإلهية، وبين دعاوى

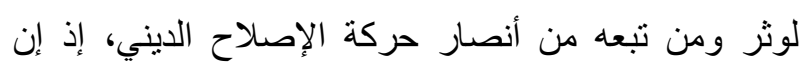

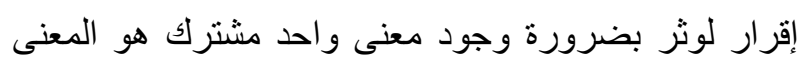

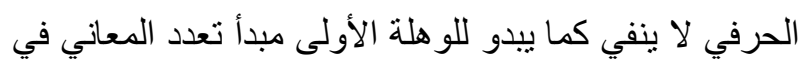

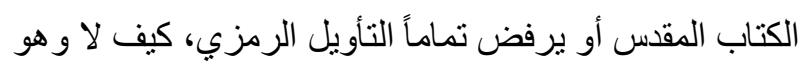
يدعو كل مسيحي إلى قراءة الكتاب على وفق رؤيته الخاصة
على العكس من ذللك فقد سارت بطريقة مستقلة عن النصوص المقسة، وبدأت النصوص المقدسة بالتقلص بشكل تدريجي

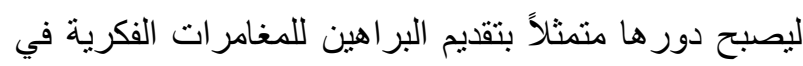

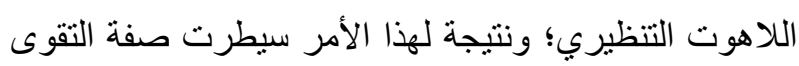
على الاهتمام بإيجاد تفسير روحاني في ثقافة العصور الوسطى المتأخرة، في حين نجد أن اللاهوت قد اتبع أجندته الأكاديمية الخاصة، ومن ثم تم التخلي عن العلاقة الديالكتيكية بين النص المقدس والتراث الحي للإيمان لصالح شكلين من التطور أخذا يزيدان بشكل مستقل في تفسير الإنجيل، ووظف لإنف

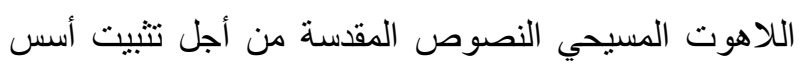
اللاهوت فيها، وقامت الروحانية المسيحية العامة بالطريقة

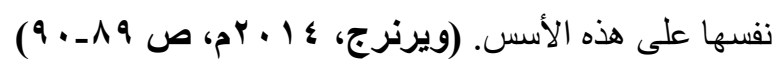
ومن الأدعية المنسوبة إلى توما الأكويني أنه يدعو الله في أن الن يهبه مهارة التفسير وهي مزية الهرمنيوطيقا، وكان مدخل

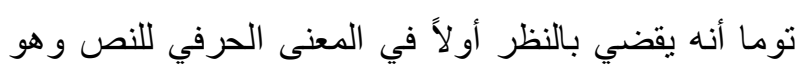
يبذل في ذلك جهداً كبيراً، وبعد ذلك ينتقل إلى المعاني المجازية، ففي تعليقاته على أرسطو يستخلص المعنى الحرفي

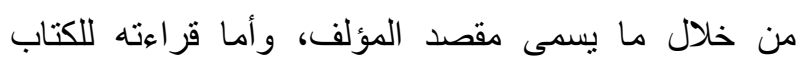
المقد فيضيف المعنى المجازي، وقد بدأ في مجموعته اللاهوتية تساؤله إن كان من الجائز في اللاهوت استعمال لغة ولة

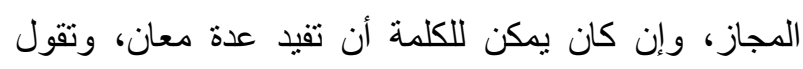

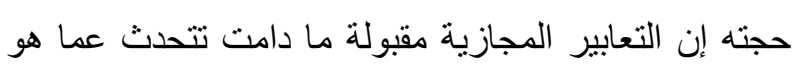

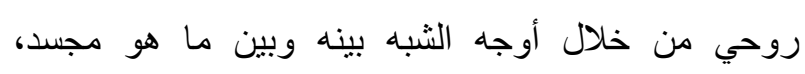
ويعترف أيضاً بوجود معانٍ منوعة في الكتاب المقدس استناداً إلى أن الله كاتب هذا الكتاب قادر على خلق الأشياء ذات المعنى لا الأصوات الناقلة للمعاني وحسب، ثم يقسم الأكويني

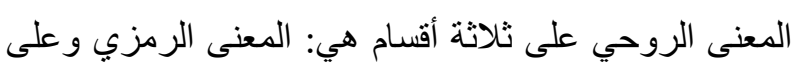

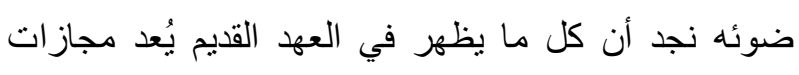

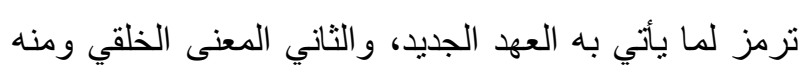
نفهم أن ما يفعله المسيح مؤشر يوجهنا إلى ما ينبخي أن نفعله لئه

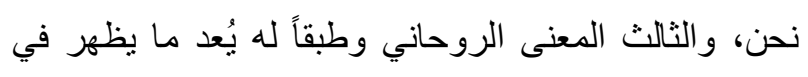

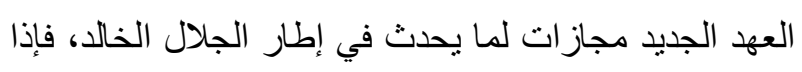
أضفنا إلى هذه المعاني الثلاثة المعنى الحرفي اتضحت لنا المعاني الأربعة التي نجدها في الكتاب المقدس. (بيشوه،

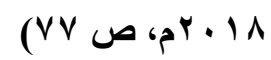


بها إلى رموز وطقوس دينية تعبر بذاتها عن الحقائق والأشياء، وهو حال الدراسات السيموطيقية اليوم لأنظمة ولئه الأكل واللباس و التواصل داخل التقافات بوصفها علاءمات

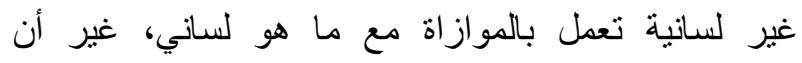

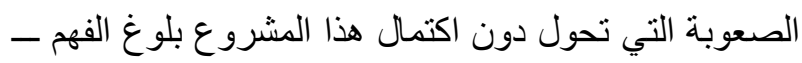
بحسب رؤية فلاسيوس - هو غموض اللغة نفسها، لكن من

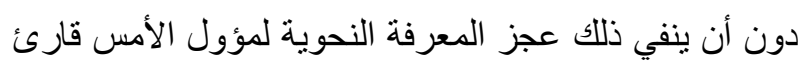
اليوم الذي يُعد بدوره مسؤولاً عن هذه الألغاز، ولكي يتم تخطي هذه العقبات إلى إدراك معاني الكتاب المقدس يقترح

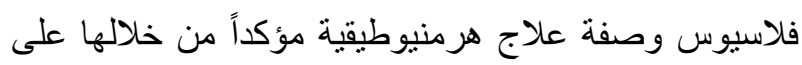

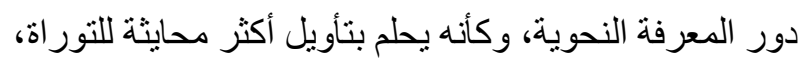

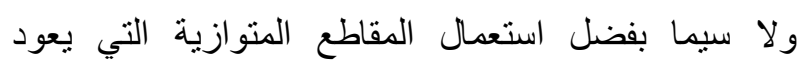
استعمالها إلى أو غسطين، و هو حين يستعيدها منه أو من غيره من آباء الكنيسة إنما يروم وصل التراث التفسيري بعضه وهنه

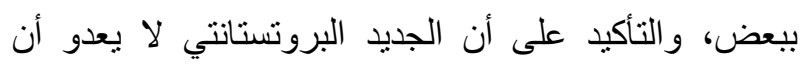

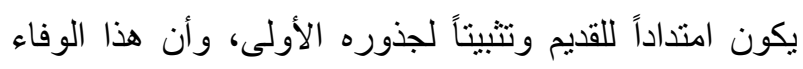
للمرجعية التراثية بوجه عام و الأوغسطينية بوجه خاص جعل ونلئل مشروع فلاسيوس يفتقد أدنى شروط إقامة هرمنيوطيقا خاصة مختلفة تدعم دعاوى الإصلاح و التجديد التي صحبت مشروعله، ومهما يكن من أمر فان ما ينبغي تأكيده هو أن وعان

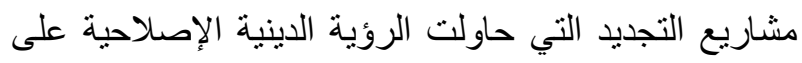

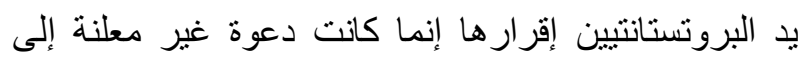
إزاحة التأويل المجازي وكل ما يمت بصلة إلى مذهب تعدد المدان المعاني في الكتاب المقس، وهو ما يجعل إقامة لسانيات دينية كما يزعم فلاسيوس وسلفه أمراً مستحيلاً، إذ كيف يكون

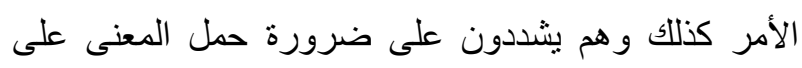
الظاهر الحرفي وما إلى ذلك في المحصلة إلا إرجاء وتعطيل لدلالات النص التي لا ترضى بغير التنأويل لما هو وراء الاء لهاء

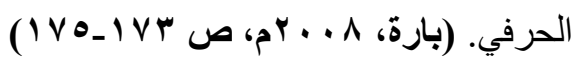

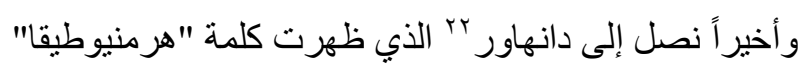
لأول مرة كعنوان رئيسي في إحدى مؤلفاته التي صدرت

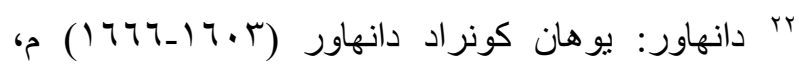
فيلسوف ألماني و عالم لغوي لوثري لاهوتي، كان أستاذاً في

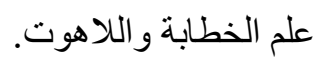

لحظة فعل التأويل، وذلك بأن يعيش تجربة إيمانية يصل فيها إلى اليقين أو المعرفة الإلهية المخبأة في تضاعيف الكتاب

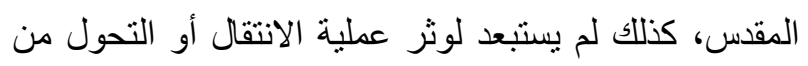
التفسير إلى التطبيق، بل أعطاها رؤية جديدة من خلال إبراز الأولوية التاريخية لكلمة الله للإنجيل الحي على سيادة القانون إنهان الجامد الذي تحول إلى كتاب، ويعتقد أن الرسالة المنجزة

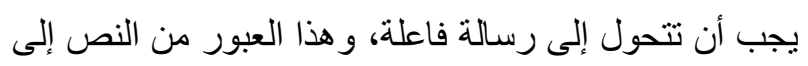
الوعظ هو عبور من الكتاب المقد إلى الكلام الثفهي،

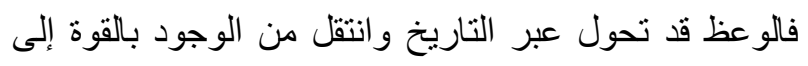
الوجود بالفعل تبعاً للموقف وليس للمعنى غير الزمني الذي

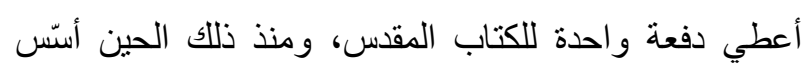

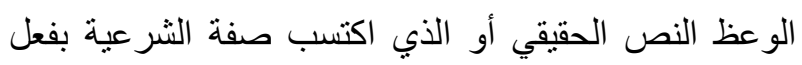
إز احته للأصل الأصيل. (بارة، A . . P م، ص IVY_IVI) وبحسب هرمينوطيقا لوثر فإن النص الديني يقرأ ضمن أربعة

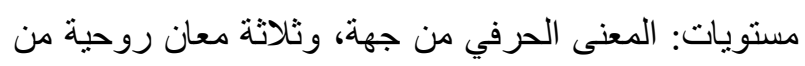
جهة أخرى، أحدها: المعنى المجازي الذي يحيل على المبادئ و المعتقدات الكلية للكنيسة، والثاني المعنى الأخلافي الذي

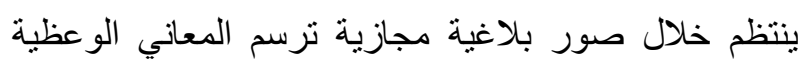
بطريقة تعبيرية تتجاوب مع إمكانات التلقي لاى المؤمن وتفتح على الممارسات اليومية، والثالث المعنى الباطني الذي يحيل على الآفاق الغيبية والروحانية غير المتحددة بالخطاب الظاهر. (الخضراوي، بلا تاريخ)

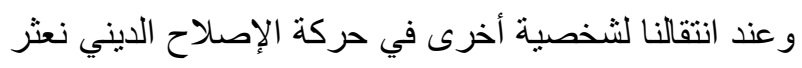

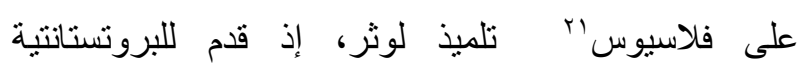
هرمنيوطيقا نموذجية وفذّة للكتاب المقدس، وذلك في مؤلفه "مفتاح الكتاب المقد"، ولقد دعا فلاسيوس إلى بناء منظومة دينية تقوم على المعرفة اللسانية والنحوية وهو بذلك يبحث عن بديل موضوعي لتأويل الكتاب المقدس ينطلق من نظام

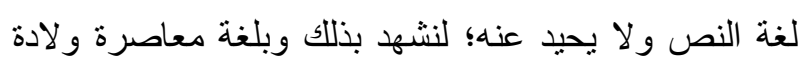
مشروع لسانيات النص الديني، ومن ثم تأويل مختلف لهذا الكتاب؛ لأن اللغة الدينية بذلك تؤسس نظامها الخاص الذي وني

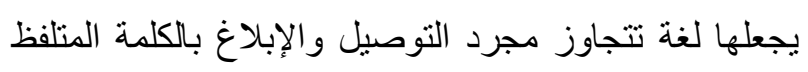

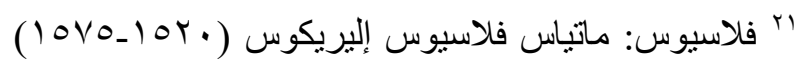
م تلميذ لوثر. 


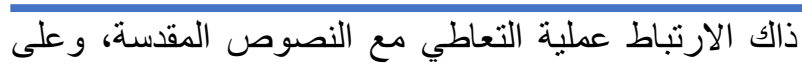
الرغم من أن الاستعمال الأول كانت جذوره نوحي إلى كل

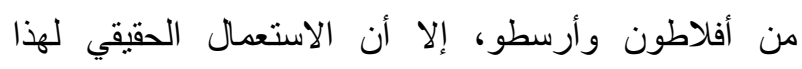

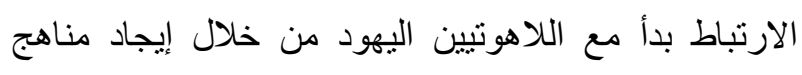
متعددة من أجل فلك الرموز المتناثرة في النصوص المقدسة

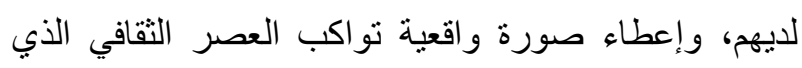
عاثها بعض فلاسفة اليهود من أمثال فيلون وابن ميمون، علماً أن النصوص المقسة غبر مقتصرة على نصوص التوراة، بل تشمل نصوص التلمود وغيرها من النصوص التي ملي أضيفت على الأسفار الخمسة الخاصة بالتور اة، ويُعد فيلون أبرز شخصية تاريخية ارتبطت مع اسمه بداية نشوء الهرمنيوطيقا الدينية. و عند الانتقال إلى الفكر المسيحي نجد العديد من الفلاسفة

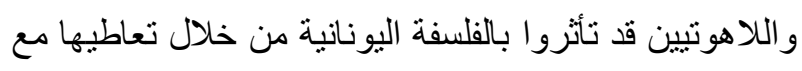
ملاحم هوميروس، وكذلك تأثر هم بالفكر اليهودي من خلال

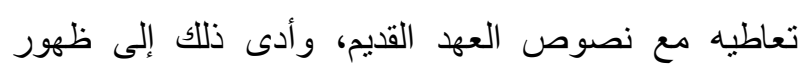

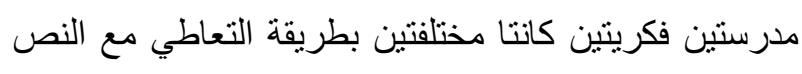
المقس، إذ وجدنا تركيزاً من لدن أصحاب مدرسة الإسكندرية على المنهج الرمزي (المجازي) في تفسيرهم

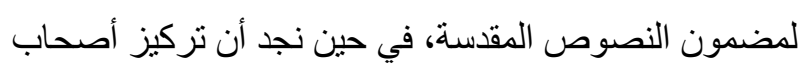
مدرسة أنطاكية كان منصباً على المنهج الحرفي في تفسير هم

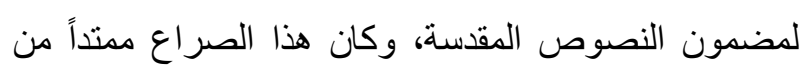
الفكر اليهودي واستمر عبر الفكر المسيحي، وازداد ضراوة ولهون مع الرؤية التي يكتنز ها بعض اللاهوتيين ورجال الدين المسيحي، فنجد منهم من يسعى إلى تكريس المنهج التأويلي

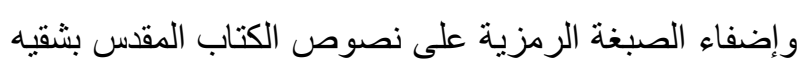
العهد القديم والعهد الجديد من أجل إيجاد تفسير مقنع للقارئ

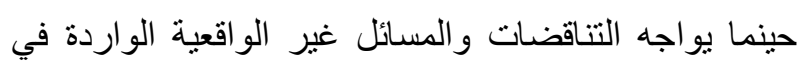
تلك النصوص، فضلاً عن التركيز على الجوانب الروحية والأخلاقية المخبأة في ثنايا تلك النصوص، ومحاولة التعايش مع حروف تللك النصوص بشكل روحاني وعدم الاكتفاء

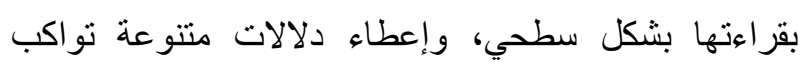
العصر الذي يعيشه القارئ، كذلك العمل على تنزيه الإله وعدم الركون إلى صفة التجسيد الموجودة ضمن نصوص لئنه الكتاب المقدس، وفي الوقت نفسه نجد أن مغزى بعض إنى رجال
باللغة اللاتينية تحت عنوان "الهرمنيوطيقا المقدة أو منهج شرح النصوص المقدة"، وقد شكّل عمل دانهاور هذا نقطة تحول في الفهم اللاهوتي بين مفسري النصوص المقدسة، ذلك بأن عمله بتضمن عنصر تميز منهجي للهرمنيوطيقا التحليلية عن المنطق التحليلي، إذ كان التفسير في السابق هو المقصود

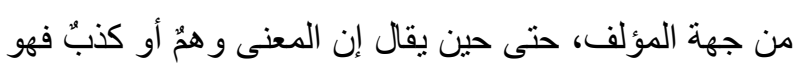

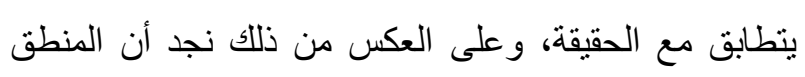

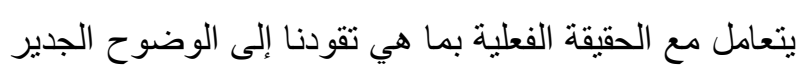

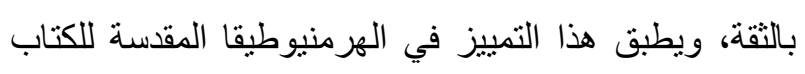
المقد بوصفها أنموذجاً لكل النصوص الأخرى، وتميز

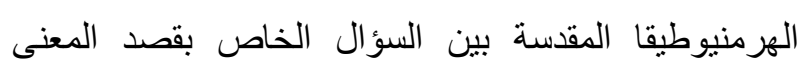

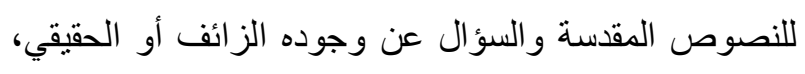
وأن قارئ الكتاب المقد يفترض أن يقرر من خلال التفسيرات عن مقصد المؤلف، ومن خلال البحث المنطقي و التحليل أو من خلال الثقة في الروح المقدسة بوصفها مؤلف الكتاب المقس، ومن ناحية أخرى فإن محتوى الثقة يميز

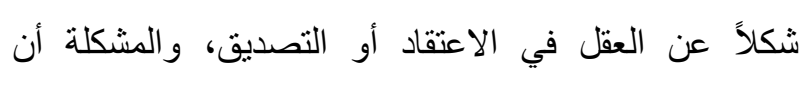

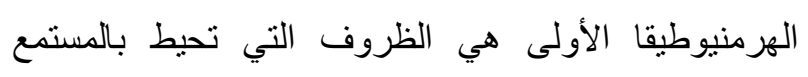
والقارئ، وأن تكون صحيحة بشكل يسمح بفهم المقصد

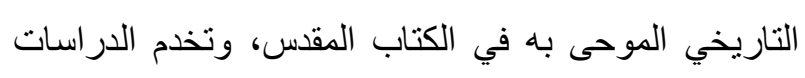
الفيلولوجية والتاريخية للكتاب المقد بدقة الفهم التاريخي لموقف الكاتب، ويثمل هذا تحديد عواطف المؤلف ووقت الكتابة، وأن الهدف النهائي هو تيسير فهم الذات ليس فقط

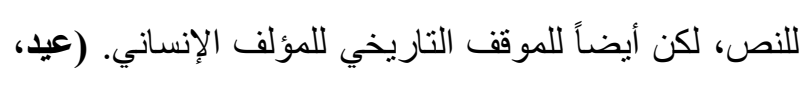

( الخائمة 17

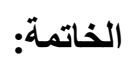

وفي الختام سنعمل على رسم صورة لمجمل الأحداث التي واجهنتا في سيرنا السابق ونحن نجوب المدارس الفكرية و الثخصيات الفلسفية واللاهوتية من خلال ما طرحوه من فن أمور تخص الهرمنيوطيقا الدينية، إذ لاحظنا مدى ارتباط

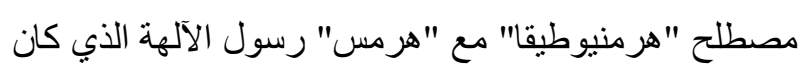
يمثل جسراً للتفاهم بين العالم الإلهي و العالم البشري من خلال رئل

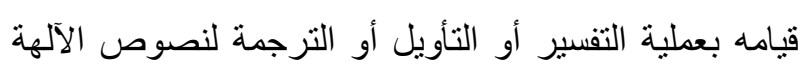
لاى اليونان القدماء، ومحاولة إيصالها بشكل واضح ومفهوم للعالم البشري، وقد استمد الفلاسفة واللاهوتيون فيما بعد من ومن 


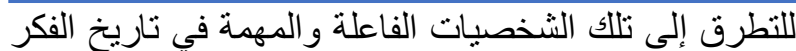

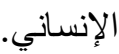

والنتيجة النهائية التي توصلنا إليها تتمثل في ضرورة الأخذ بالمنهج الهرمنيوطيقي في أثناء قراءة النص المقس؛ من أجله كثف اللثام عن المضمون الخفي الذي يقبع خلف الكلمات الظاهرة للعيان، وأن عملية الاكتفاء بتفسير واحد للنص قد يؤدي إلى موته وتوقفه في زمن تفسيره؛ لعدم استطاعته مواكبة التطورات والتغييرات العلمية والفكرية ونشوء المناهج الفيلولوجية و النقدية، ما يعني أن لكل زمان وجهة

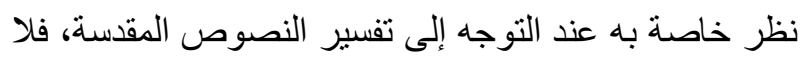
يعقل أن نفسر نصاً دينياً في زمن لم تعرف فيه التكنلوجيا المعاصرة بكافة أشكالها التفسير نفسه في وقتنتا الحالي، لهني، فالسلاح ـ على سبيل المثنال لا الحصر ــ الذي كان مقتصر اً على السيف والرمح و السهم اختلف مضمونه اليوم مع البندقية

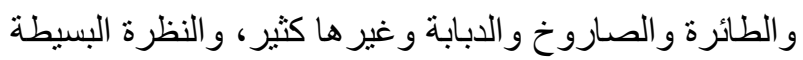

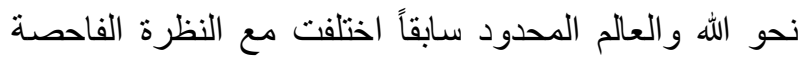
عبر المجهر و التلسكوب و السفر إلى الفضاء والغوص في الهي عمق البحار والوصول إلى أماكن لم تطؤها قدم إنسان من ون ولن قبل، فضلاً عن التطور الذي صاحب اللغات بجميع أنواعها، كل ذلك و غير ها من المسائل يحتم علينا أن لا نقف عند تفسير واحد أو منهج واحد عند قراءتنا للنص المقدس، ونحن بهذه الطريقة نمارس عملية إحياء جديدة، و إعطاء ديمو مة مستمرة لتنلك النصوص المقدسة.

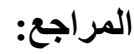

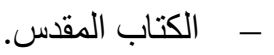

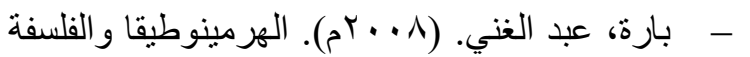
/ نحو مشروع عقل تأويلي. الجزائر: منشورات

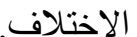

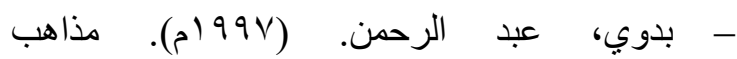
الإسلاميين. بيروت، لبنان: دار العلم للملايين.

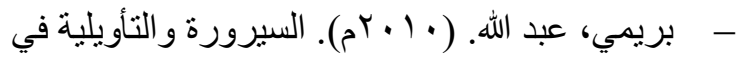
هرمينوسيا هانس جورج غادامير وبول ريكور. الشارقة، الإمارات العربية المتحدة: دائرة الثقافة

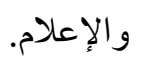

الدين المسيحي كان مختلفاً في الغاية من تأكيده على المنهج الرمزي، وذللك من أجل حصر فهم النصوص المقسة في إطار الكنيسة ورجالاتها، وعدم إعطاء فرصة للقارئ من خارج هذا الإطار في فهم النص المقدس وتفسيره؛ لكي ييقى الجميع تحت سلطتهم و هم الطبقة الوحيدة التي تفسر مضامين تللك النصوص بحسب مقتضيات مصالحهم الثخصية، وهو ما أثار ردة فعل من لان بعض المفكرين المسيحيين أمثال مارنن لوثر وغيره في القيام بحركة الإصلاح الديني، وانتزاع السلطة من رجال الكنيسة فيما يخص قراءة النص المقس وتفسيره و ونحها لعامة الناس، ناهيك عن وجود العديد من الفلاسفة واللاهوتيين المسيحيين الذين كانوا يعتقدون أن

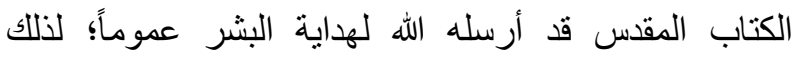
يفترض أن يكون و اضحاً ومفهوماً لدى الجميع. وعلى الرغم من بروز مناهج عدة في تفسير النص المقد، سواء بالفكر اليهودي أو بالفكر المسيحي، مثل المنهج المعتمد على التفسير الحرفي، وآخر على التفسير الرمزي، وثنالث على التفسير الأخلاقي، ورابع على التفسير الروحاني و غير ها، إلا أن التفسير الرمزي والتفسير الحرفي كانا أبرز منهجين طغيا على السطح حين يتم التعاطي مع النصوص المقدة، وقد تم التطرق إلى مجموعة من الثخصيات الفكرية التي أوجدت مناهج معينة لتفسير النص المقدس في الفكر المسيحي، وكان من أشهر ها أوريجانوس و أوغسطين وتوما الأكويني، ويُعد أوغسطين أبرز شخصية هرمنيوطيقية في الفكر المسيحي، وكان لها تأثير كبير في الدراسات الهرمنيوطيقية في العصور التي تلت عصره، وقد سعى حثيثاً إلى التوفيق بين منهجي مدرسة الإسكندرية ومدرسة أنطاكية من خلال إيجاده لمنهج يقوم على المنهجين سوية، واختمنا مسيرتنا مع دانهاور الذي ظهرت كلمة "هرمنيوطيقا" لأول مرة بالتاريخ كعنوان رئيسي لإحدى مؤلفاته، ومن بعده بدأت

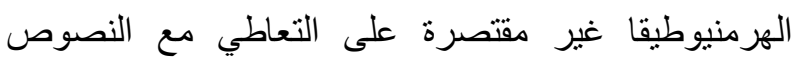
المقدة؛ إذ نجدها قد توسعت لتشمل النصوص الأدبية و القانونية و الفلسفية وغير ها من العلوم الإنسانية والاجتماعية، وبرز في هذا المضمار العديد من الفلاسفة الذين لا يتسع البحث الحالي لذكرهم، ونأمل أن تكون لنا دراسة لاحقة 


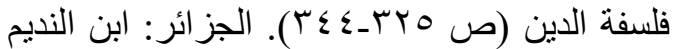
للنشر و التوزيع.

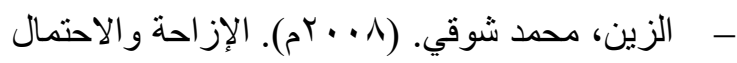
/ صفائح نقدية في الفلسفة الغربية. بيروت، لبنان:

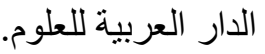

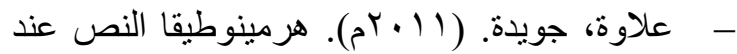
بول ريكور من خلال كتابه "من النص إلى الفعل" مقاربة تأويلية. كلية الآداب و اللغات. الجزائر: جامعة سطيف.

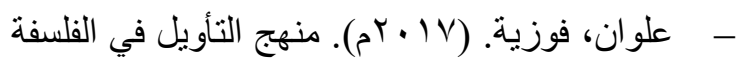
اليهودية / موسى ابن ميمون نموذجاً. مجلة

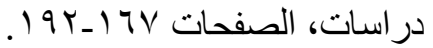

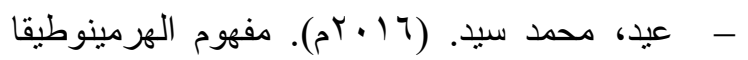
في فلسفة هايدغر / الاتصال بالكائن كمنهج للفهم.

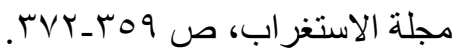

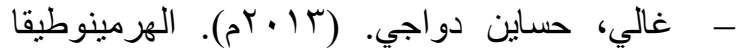
وإتيقا التخاطب. الجزائر: جامعة وهران - كلية

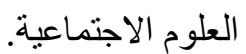
- قنديل، عبد الرزاق أحمد. (9^اجم). الأثر الإسلامي في الفكر الديني اليهودي. القاهرة، مصر: جامعة عين شمس - مركز بحوث الثرق الأوسط.

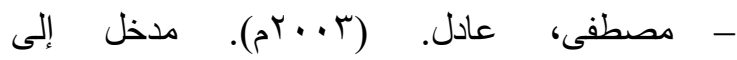
الهرمنيوطيقا / نظرية التأويل من أفلاطون إلى جادامر. بيروت، لبنان: دار النهضة العربية.

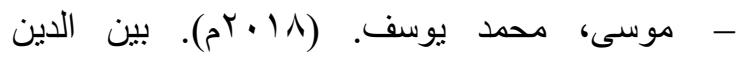
والفلسفة / في رأي ابن رشد وفلاسفة العصر الوسيط. المملكة المتحدة: مؤسسة هنداوي سي آي

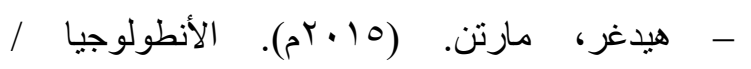
هرمينوطيقا الواقعانية. (عمارة الناصر، المترجم) بغداد، العر اق: منثورات الجمل. - ويرنرج، جينروند. (ع ا.rم). تطور الهرمنيوطيقا اللاهوتية / من البدايات إلى عصر التنوير. (عبد
- - بن ميمون، موسى. (بلا تاريخ). دلالة الحائرين (المجلد (). (حسين أتاي، المترجم) القاهرة، مصر :

مكتبة الثقافة الدينية.

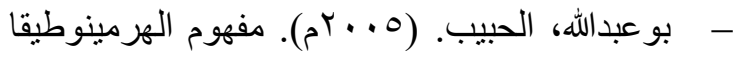
/ الأصول الغربية والثقافية العربية. مجلة

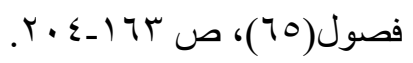

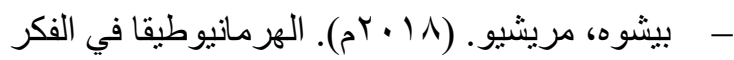
القروسطي. تأليف موسوعة الهرمانيوطيقا (محمد عناني، المترجم، المجلد (، ص سا7-. 9). القاهرة، مصر : المركز القومي للترجمة.

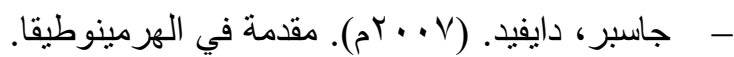
(وجيه قانصو، المترجم) الجزائر: منشورات الاختلاف. - الجبوري، عماد الدين. (1/ ل دراسة في تطور الفكر الإنساني. لندن: منشورات إي كتب - - الخضراوي، محمد أحمد. (بلا تناريخ). الوعي الهرمينوطيقي وتجديد الفهم الديني / جدلية الإحالة والإستحالة. تم الاسترداد من الملتقى الفكري للإبداع: http://almultaka.org/site.php?id=827\&i $\mathrm{dC}=2 \& \operatorname{idSC}=6$

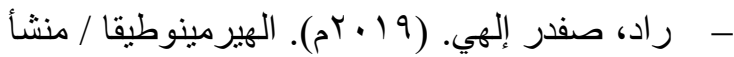
المصطلح ومعناه واسستعمالاته في الحضار ات الإنسانية المختلفة.(حسنين الجمال، المترجم) بيروت، لبنان: العتبة العباسية المقدة، المركز

$$
\text { الإسلامي للار اسات الاستر اتيجية. }
$$

- روشن، محمد باقر سعيدي. (T 1 (r)م). منطق الخطاب القرآني / در اسات في لغة القرآن). (رضا شمس الدين، المترجم) بيروت، لبنان: مركز الحضارة لتنمية الفكر الإسلامي. - زيد، عامر عبد. (VIV) والتأويل عند فيلون الإسكندري. تأليف عامر عبد زيد و شريف الدين بن دوبه (المحرر)، مدخل الى لى 


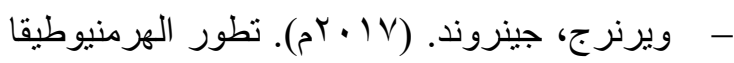
اللاهوتية / من البدايات إلى عصر التنوير. تأليف هيترون عبد الجبار الرفاعي، الهرمنيوطيقا والتفسير الديني للعالم (ص 99_97). تونس: دار التنوير للطباعة

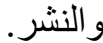

